\title{
Prirodna obilježja Svilaje s pregledom istraživanja flore i vegetacije
}

\author{
MILENKO MILOVIĆ ${ }^{*}$, NENAD JASPRICA ${ }^{2}$, DAMIRA TAFRA ${ }^{3}$, MARIJA PANDŽA $^{4}$, VESNA KRPINA \\ ${ }^{1}$ Gimnazija Antuna Vrančića i Medicinska škola Šibenik, HR-22000 Šibenik, Hrvatska \\ ${ }^{2}$ Institut za more i priobalje, Sveučilište u Dubrovniku, P.O. Box 83, HR-20000 Dubrovnik, Hrvatska \\ ${ }^{3}$ Ravnice 20, 21310 Omiš, Hrvatska \\ ${ }^{4}$ Osnovna škola Murterski škoji, Put škole 8, HR-22243 Murter, Hrvatska \\ ${ }^{5}$ Branimira Gušića 3, HR-23000 Zadar, Hrvatska
}

* Autor za dopisivanje / corresponding author: milenko.milovic@si.t-com.hr

Tip članka / article type: pregledni rad / review paper

Povijest članka / article history: primljeno / received: 20.10.2019., prihvaćeno / accepted: 26.4.2020.

URL: https://doi.org/10.46232/glashbod.8.1.5

Milović, M., Jasprica, N., Tafra, D., Pandža, M., Krpina, V. (2020): Prirodna obilježja Svilaje s pregledom istraživanja flore i vegetacije. Glas. Hrvat. bot. druš. 8(1): 29-50.

\section{Sažetak}

Svilaja (1508 m n. v.) je planina u Dalmatinskoj Zagori, u središnjem dijelu unutrašnje Dalmacije. Flora i vegetacija planine Svilaje do sada nije sustavno istraživana. Od 2013. obavljaju se opsežna terenska istraživanja s ciljem inventarizacije ukupne flore. $\mathrm{U}$ ovom radu su, na temelju dostupnih podataka iz literature, prikazana obilježja reljefa, klime i fitogeografski položaj s općim pregledom vegetacije. U glavnom dijelu rada prikazan je detaljni pregled dosadašnjih istraživanja flore i vegetacije Svilaje. Analizirani su samo oni literaturni podaci o nalazima biljnih svojti i zajednica čija su nalazišta (lokaliteti) unutar granica istraživanog područja. Prema analiziranim literaturnim podacima, do sada je za područje Svilaje zabilježeno približno 700 svojti vaskularne flore, među kojima je značajan broj endemičnih, ugroženih i zaštićenih svojti kao npr.: Arenaria orbicularis, Astragalus monspessulanus ssp. illyricus, Crocus biflorus ssp. weldenii, Dianthus sylvestris ssp. tergestinus, Edraianthus tenuifolius, Hyacinthella dalmatica, Pulsatilla grandis, Thymus bracteosus, itd. Prema dosadašnjim saznanjima Svilaja se odlikuje iznimno bogatom florom orhideja (Orchidaceae): Coeloglossum viride, Dactylorhiza maculata, Gymnadenia conopsea, Listera ovata, Ophrys apifera, O. dinarica, O. tetraloniae, Orchis militaris, O. morio, O. tridentata, Platanthera chlorantha, itd. Točan broj prethodno zabilježenih svojti i biljnih zajednica nije moguće preciznije utvrditi zbog razlika u shvaćanju granica Svilaje i nepreciznom navođenju lokaliteta u prethodno objavljenim radovima. Podaci o dosadašnjim istraživanjima neophodno su polazište za sustavna istraživanja flore Svilaje koja su u tijeku. Na neophodnost sustavnih istraživanja flore Svilaje ukazuje starost većine zabilježenih nalaza i značajne promjene u biljnom pokrovu uzrokovane snažnom depopulacijom i smanjivanjem intenziteta tradicionalnog stočarstva i poljodjelstva te brojnim požarima.

Keywords: Endemi, flora, klima, orhideje, povijesni pregled, reljef, Svilaja, vegetacija 


\title{
Milović, M., Jasprica, N., Tafra, D., Pandža, M., Krpina, V. (2020): The natural features of the Svilaja mountain with references of historical investigations of flora and vegetation. Glas. Hrvat. bot. druš. 8(1): 29-50.
}

\begin{abstract}
Svilaja Mt (1508 m a.s.1.) is a mountain located in the central part of the hinterland of Dalmatia, i.e. in Dalmatian Zagora. Until now, the flora and vegetation of the Svilaja Mt. have not been systematically investigated. Based on the analysis of the literature, in this paper the general characteristics of the relief, climate and phytogeographic position of the Svilaja Mt, with general overview of vegetation, are presented. The paper also provides a detailed overview of the data on previous research of the flora and vegetation of the mountain. These analyses were necessary as a starting point for planning and conducting extensive field research in order to inventory the total flora underway since 2013. Here, we analysed only literature data on findings of the plant taxa and communities recorded on the localities within the boundaries of the study area. Based on our study on existing literature, about 700 vascular plant taxa have been reported so far in the Svilaja Mt, including a significant number of endemic, endangered and protected taxa, such as: Arenaria orbicularis, Astragalus monspessulanus ssp. illyricus, Crocus biflorus ssp. weldenii, Dianthus sylvestris ssp. tergestinus, Edraianthus tenuifolius, gentiana dinarica, Hyacinthella dalmatica, Pulsatilla grandis, Thymus bracteosus, etc. To the present knowledge Svilaja Mt is characterized by an extremely rich and diverse orchid flora (Orchidaceae): Coeloglossum viride, Dactylorhiza maculata, Gymnadenia conopsea, Listera ovata, Ophrys apifera, O. dinarica, O. tetraloniae, Orchis militaris, O. morio, O. tridentata, Platanthera chlorantha, etc. Due to differences in the understanding of the mountain ranges and inconsistencies in localities indication the exact number of plant taxa and communities previuosly recorded in literature has not been determined more precisely. Most of the information are old and there have been no systematic updating. In addition, significant changes in the vegetation cover caused by the strong depopulation, reduction of the intensity of traditional livestock and agriculture, and numerous fires. Due to these facts, more in-depth studies are required to determine mountain flora and vegetation.
\end{abstract}

Keywords: Climate, endemics, flora, historical overview, orchids, relief, Svilaja Mt, vegetation

\section{Uvod}

Svilaja je planina u Dalmatinskoj Zagori, u središnjem dijelu unutrašnje Dalmacije. Od 2013. u tijeku su sustavna terenska istraživanja flore planine Svilaje u granicama prikazanim na slici 1. U pripremi za terenska istraživanja obavljena je temeljita analiza literaturnih podataka o prirodnim obilježjima te posebno o dosadašnjim istraživanjima flore i vegetacije Svilaje. Analizirani su samo oni literaturni podaci o nalazima biljnih svojti i zajednica čija su nalazišta (lokaliteti) unutar granica istraživanog područja (sl. 1).
Kao polazište za uvid u istraživanja Svilaje do početka 20. stoljeća, poslužili su pregledni radovi o istraživanju flore i vegetacije Dalmacije (Visiani 1826, 1842, Beck Mannagetta 1901, Forenbacher 1913, 1914). Podaci o istraživanjima od početka 20. stoljeća do danas, preuzeti su iz Flora Croatica Database (FCD, Nikolić 2019), gdje su navedeni literaturni izvori nalaza biljnih svojti za Svilaju. Tijekom istraživanja pronađen je određeni broj stručnih (Kranjčev 2002, 2005, 2006, Jedlovski 1952, Meštrović 1972, Čović 2017, itd.) i znanstvenih 
radova (Janchen 1910, Marković 1992, Trinajstić 1992, Vladović i sur. 2012, 2019, itd.) s nalazima biljnih svojti i zajednica s lokaliteta na Svilaji, a koji nisu evidentirani u FCD.

Nomenklatura biljnih svojti u radu je usklađena prema Nikoliću (2019), a viših sintaksonomskih jedinica prema Terzi (2015), Mucina et al. (2016) te Škvorc et al. (2017). U ovom prikazu nazivi biljnih asocijacija izvorno su preuzeti iz publikacija bez prethodnog nomenklaturnog usklađivanja. Pri navođenju primjera prethodno zabilježenih svojti, uz nazive prema Nikoliću (2019) navedeni su i nazivi svojti kako ih navode autori u izvornim radovima.

Cilj ovog rada je sagledavanje dosadašnjeg stanja istraženosti biljnog pokrova Svilaje što će poslužiti kao polazna osnova za uspješno planiranje i provođenje terenskih istraživanja inventarizacije ukupne vaskularne flore.

\section{Prirodna obilježja Svilaje}

\section{Geografski položaj}

Svilaja je planina u Dalmatinskoj Zagori koja se proteže smjerom sjeverozapad-jugoistok između Petrovog i Sinjskog polja u dužini oko $40 \mathrm{~km}$. Sastavni je dio primorskog pojasa dinarskog gorja, gdje zajedno s Prominom, Velikim Kozjakom, Mosećom i Vrgorskim gorjem čini središnji niz

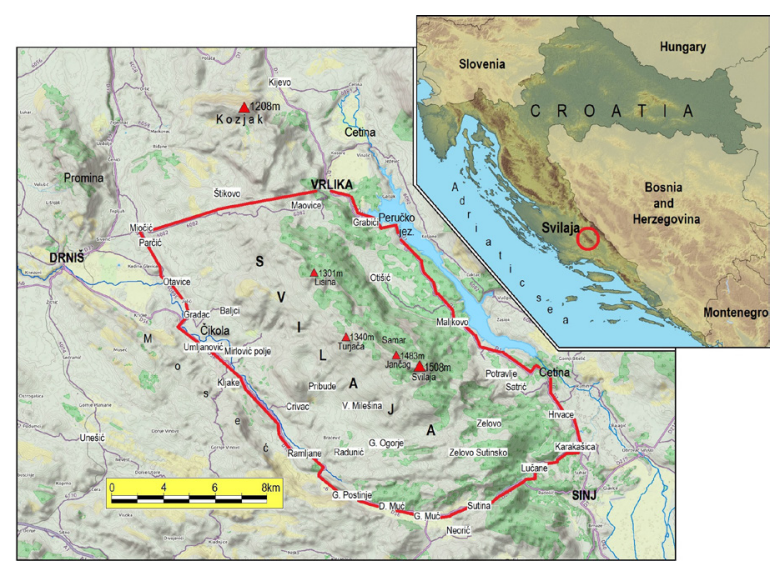

Slika 1. Geografski položaj Svilaje i granice istraživanog područja. dalmatinskih planina, smješten između višeg graničnog lanca (prema BiH) Ilica - Dinara Troglav - Kamešnica i obalnog niza planina Kozjak - Mosor - Biokovo - Rilić. Najviši vrh Svilaje je Bat ili Svilaja (1908 m), sjeverno od Sinja, približno $35 \mathrm{~km}$ udaljen od mora (Kaštelanski zaljev). U sjeverozapadnom dijelu (od Vrlike prema Kninu), na Svilaju se nadovezuje greben Velikog Kozjaka, od nje odvojen cestom Drniš - Vrlika i prijevojem Lemeš (860 m). Sjeveroistočnim podnožjem Svilaje prolazi cesta Knin - Vrlika - Sinj, zapadnim Knin Drniš - Šibenik, a jugozapadnim Drniš - Muć - Split.

\section{Geološke značajke}

Najveći dio lanca Svilaje je valoviti krški greben s naizmjeničnim nizom vrhova i ponikava (vrtača) te više krških jama i špilja. Od najvišeg vrha (1508 m), u južnom dijelu Svilaje iznad Sinja, na sjever prema Vrlici protežu se sve niži grebeni, Jančag (1483 m), Turjača (1340 m), Veliki vrh (1304 m) i Lisina (1301 $\mathrm{m})$. Za razliku od većine ostalih naših planina $u$ priobalnom pojasu, čije su primorske padine strmije od kontinentalnih, na Svilaji se jugozapadne padine postupno spuštaju u zaobljenom terasastom reljefu, dok se naprotiv unutrašnji sjeveroistočni grebeni s najvećim vrhovima (Svilaja-Jančag) strmo obrušavaju oštrijim odsjecima prema Peručkom jezeru. Upravo na tim strmim i zasjenjenim sjeveroistočnim padinama Svilaje, zbog svježije i vlažnije klime, dolaze najprostranije i najbujnije visoke šume na cijelom području Dalmacije (Lovrić i sur. 1987).

Opći podaci o geološkoj građi Svilaje mogu se pronaći u Osnovnoj geološkoj karti 1:100000, listovi Drniš i Sinj i pripadajućim tumačima (Ivanović i sur. 1977, 1978, Papeš i sur. 1982, Rajić i sur. 1984). Posebno su istraživane geološke naslage u okolici Vrlike (Ivanović 1971), Muća (Šušnjara \& Šušnjara, 1983) i Ogorja (Sremac i sur. 2017).

Istraživano područje pripada tektonskoj jedinici Svilaja (Raić i sur., 1984), u kojoj se pojavljuju naslage trijasa, a sastoji se od slijeda sedimenta do donje krede, uz zabilježene transgresivne granice 
s donjom jurom i donjom kredom (Papeš i sur. 1982). Kao najstarije naslage pojavljuju se donjo trijaski klastiti s proslojcima vapnenaca (tzv. „sajske naslage“), dok se u gornjem dijelu donjeg trijasa pojavljuju vapnenci i lapori (tzv. „kampilske naslage“). U naslagama srednjeg trijasa nalaze se vulkanoklastične stijene. Na srednji trijas transgresivno dolaze jurske breče, vapnenci i dolomiti (Papeš i sur. 1982). Slijed naslaga nastavlja se jurskim vapnencima i dolomitima te je gornja jura obilježena taloženjem vapnenaca s kladokoropsisima i vapnencima s klipeinama. Ovakav je razvoj uočen i u ostalim dijelovima Vanjskih Dinarida (Sinj, Knin, Drniš, Udbina) (Papeš i sur. 1982, Jelaska et al. 2003) i odnosi se na taloge Jadranske Karbonatne Platforme (Vlahović et al. 2005). Transgresivna granica s donjom kredom obilježena je pojavom vapnenaca sa salpingoporelama te rjeđe dolomitima i lećama breča (Raić i sur. 1984). S južne strane tektonska jedinica Svilaja je ograničena tektonskom jedinicom Visoka-Visočica gdje dolazi kao navlaka na spomenutu jedinicu. Naslage donjeg i srednjeg trijasa tektonske jedinice Svilaja padaju prema sjeveru pod kutom od $30^{\circ}$ do $45^{\circ}$.

Za razliku od susjednih Dinare i Kamešnice u čijem sastavu prevladavaju vapnenci kredne starosti, Svilaja se odlikuje znatno raznovrsnijom litološkom podlogom (Lovrić i sur. 1987). Središnji, najviši greben sastavljen je pretežno od vapnenaca i to pretežno jurske i trijaske starosti (Kerner 1907, 1915, Bojanić 1961). U okolici sela Maovice nalaze se i trošnije vapnenačke breče, a dolomiti su zastupljeni na južnim padinama Svilaje prema Muću i Sinju, kao i u masivu Velikog Kozjaka. Na Svilaji dolaze i silikatni tereni u obliku metamorfnih

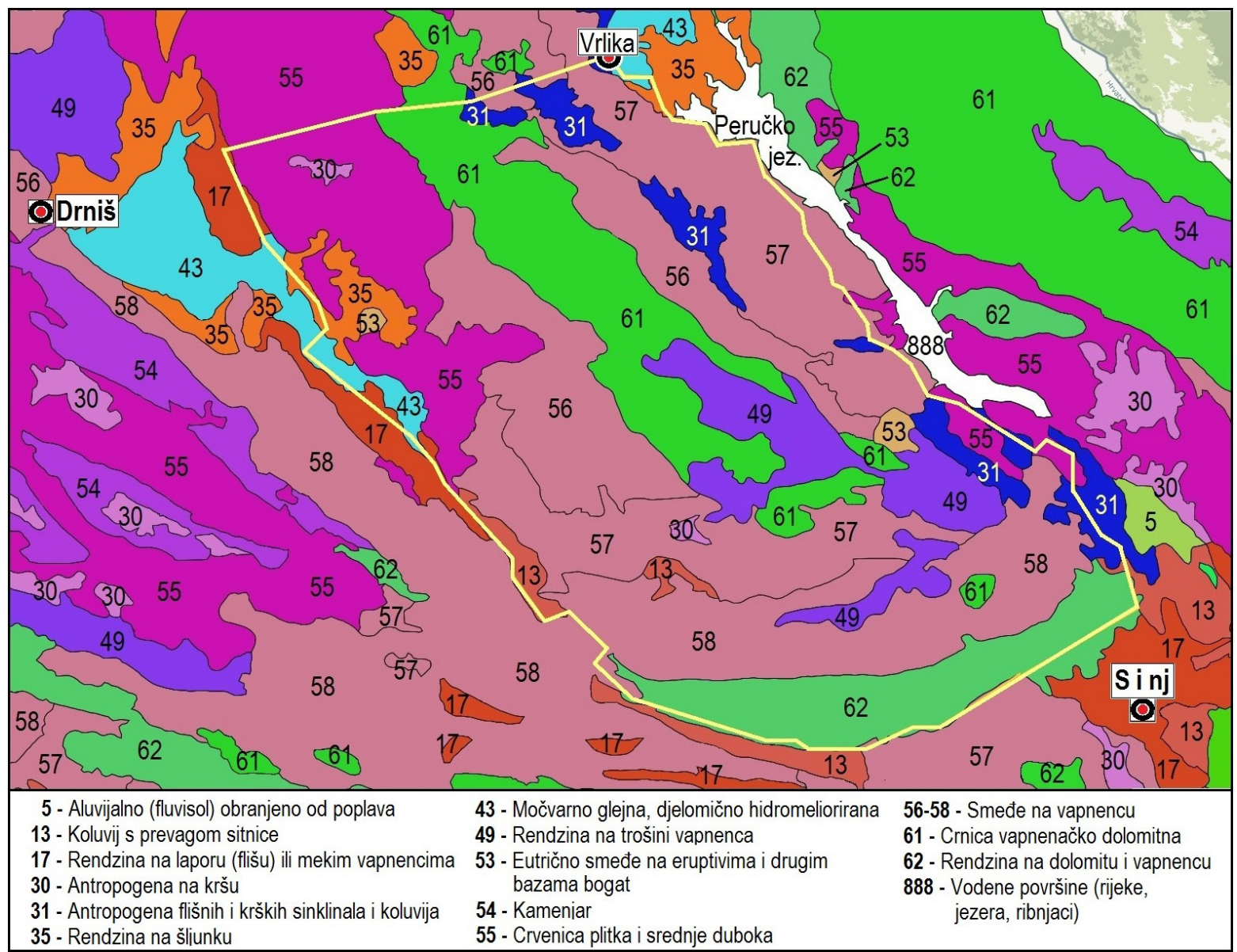

Slika 2. Tla Svilaje i okolnog područja (izdvojeno i prilagođeno prema Interaktivna digitalna pedološka karta $R H$, prema Vukadinović 2019, http://tlo-i-biljka.eu/GIS.html). 
stijena (Werfenski škriljavci), npr. u okolica Muća, dok su eruptivne stijene utvrđene u okolici Vrlike i Sinja (Barić 1957). U podnožju Svilaje su značajna nalazišta, evaporitnih stijena i gipsanih lapora naročito u okolici Sinja i Vrlike. Specifičnost Svilaje je u razmjerno slaboj zastupljenosti prostranih ploha vapnenačkih stijena i točila, a značajnoj zastupljenosti dolomitnih, gipsnih i škriljevastih točila i siparišta s vrlo specifičnom vegetacijom kakvu ne nalazimo u drugim dijelovima našeg primorja (Lovrić i sur. 1987).

\section{Pedološke značajke}

Tla na području Svilaje nisu posebno istraživana. Podaci o zastupljenosti i rasprostranjhenosti tipova tala na Svilaji i okolnom području mogu se sagledati iz Osnovne pedološke karte RH (sl. 2).

Prevladavaju smeđa tla na vapnencu (sl. 2., kodovi 56-58), koja obuhvaćaju oko 50\% ukupne površine istraživanog područja. Od ostalih tipova zastupljenija su vapnenačko dolomitna crnica (61), plitka i srednje duboka crvenica (55), rendzina na dolomitu i vapnencu (62) te rendzina na trošini vapnenca (49). Navedeni tipovi tla karakteristična su za cijelo krško područje Hrvatske, a uglavnom su nepogodna ili ograničeno pogodna za uzgoj biljaka zbog male dubine, prevelike propusnosti za vodu, slabe sorptivne sposobnosti (zbog teksturnih, strukturnih i kemijskih svojstava) te podložnosti eroziji (Bogunović i sur. 2006). Erozija tla je trajan proces koji najviše ovisi o nagibu podloge, intenzitetu i količini oborina, osobinama tla (teksturi, dubini, skeletnosti i kamenitosti) te pojavi i intenzitetu pokrovnosti. Erozija je najizraženija na područjima većeg nagiba, gdje su tla izrazito plitka, a erozijski akumulati se stalno prenose $\mathrm{u}$ niže predjele i krška polja (Bogunović i sur. 2006). Problem erozije tla djelovanjem bujičnih potoka naročito je naglašen na južnim padinama Svilaje (Ogorje, Muć) gdje se nastoji ublažiti regulacijom vodotoka i pošumljavanjem nasadima crnog bora (Durbešić i Milković 2005, Čović 2017). Tla pogodna za poljoprivrednu proizvodnju, kao npr. aluvijalna tla (fluvisol, 5) i koluvij s prevagom sitnice (13) na istraživanom području Svilaje zauzimaju neznatne površine (sl. 2).

\section{Hidrološke značajke}

Specifičnost krškog reljefa općenito, pa tako i reljefa šireg područja Svilaje, je specifična podzemna cirkulacija vode, dok je većina površinskih tokova povremenog i bujičnog karaktera. Oborinske vode na vapnenačko-dolomitnoj geološkoj podlozi brzo se infiltriraju u tlo i protječu podzemnom mrežom vodotoka. Planinski lanac Svilaje predstavlja granicu koja razdvaja sliv rijeke Krke, od sliva Cetine (sl. 3). Prema Okvirnoj direktivi o vodama (DIREKTIVA 2000/60/EC) u Hrvatskoj su određene cjeline podzemnih voda na Jadranskom slivu (Brkić i sur. 2006), a zatim je utvrđeno stanje i procjena rizika podzemnih voda na područjima koja su u direktnoj vezi s površinskim vodama i kopnenim ekosustavima ovisnim o podzemnim vodama (Biondić i sur. 2009, Brkić i sur. 2016). U navedenim radovima, među ostalim, detaljno su obrađene hidrogeološke značajke slivova Krke i Cetine.

Sliv Čikole (sastavni dio sliva Krke) se sastoji iz dva dijela: sliva izvora Čikole te sliva rijeke u području izgrađenom od nepropusnih naslaga u Petrovu polju. Sliv Čikole (kojem pripada i izvorište i tok Vrbe) zauzima sjeverozapadnu padinu planine Svilaje od Petrova polja do Muća. Od površinskih tokova su potok Vrba i Čikola nizvodno od izvora koji teku jugozapadnim dijelom sliva. U ljetnim mjesecima vodotoci presuše a voda se u izvoru Čikola povuče u podzemni pećinski dio. Slivu pripadaju i povremeni izvori Velika i Mala Kanjevača (Brkić i sur. 2016). Iz izvora Čikole pitkom vodom se opskrbljuje grad Drniš i nekoliko okolnih naselja. Sa sjeverozapadnih padina Svilaje oborinske vode teku kroz podzemlje i najvećim se dijelom ulijevaju u potok JarugaKosovčica, čije se vode kod Knina ulijevaju u Krku.

Središnju ulogu u cjelini podzemnih voda ima rijeka Cetina čiji se vodotok probija od područja Vrlike preko Sinjskog polja dubokim kanjonom do 


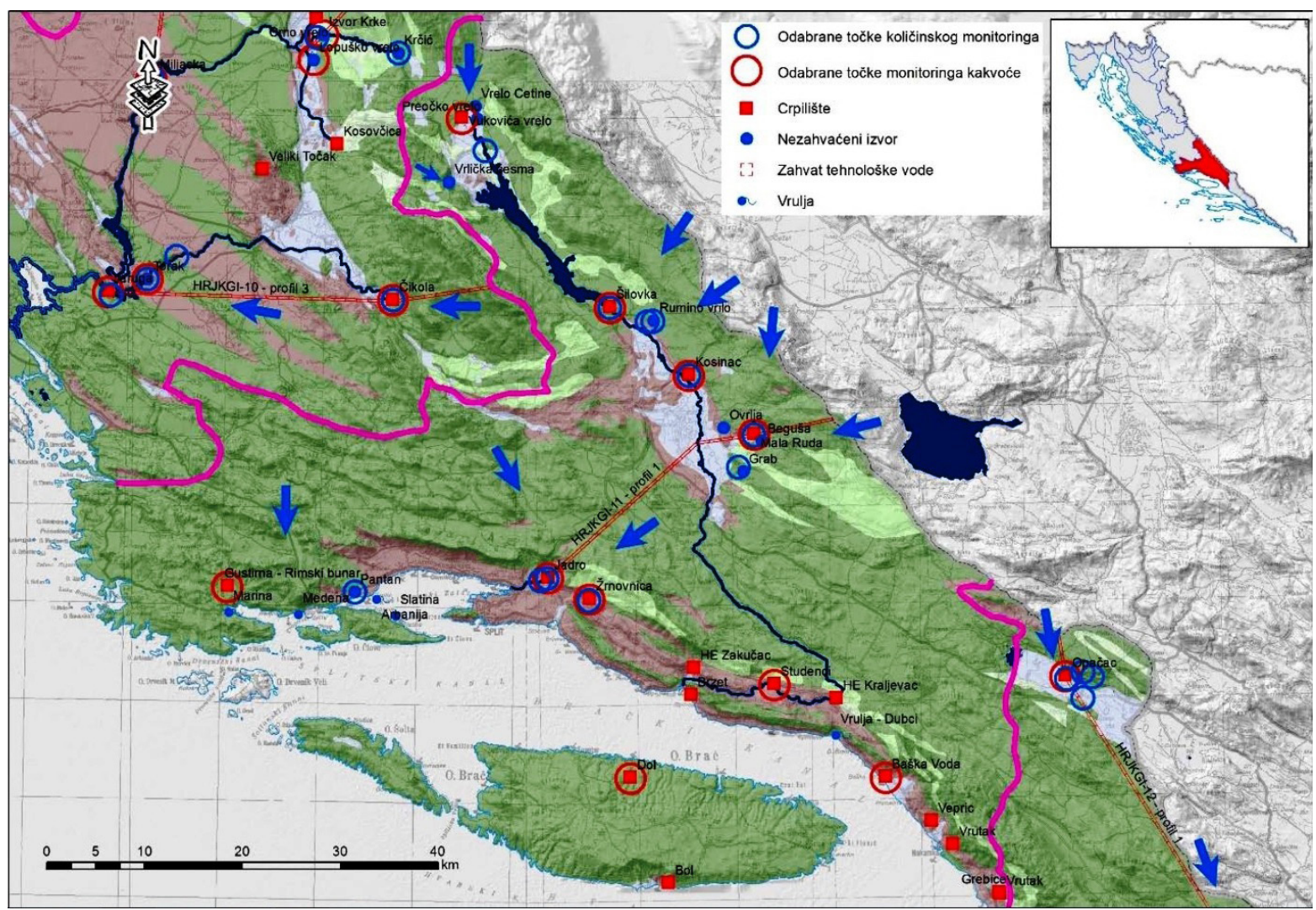

Slika 3. Granični položaj Svilaje između slivova rijeka Krke i Cetine (prema Brkić i sur. 2016; plave strelice označavaju smjer kretanja podzemnih voda).

svog ušća u more kod Omiša. Početni izvor rijeke Vukovića vrelo (uz naselje Cetina) i cijeli niz krških izvora u zoni izviranja na području Cetinskog polja daju najveću količinu vode rijeke Cetine, koja je vezana za dotoke iz planinskog područja Dinare (Brkić i sur. 2006). Planina Dinara ima generalno sinklinalnu formu i ne predstavlja barijeru kretanju podzemne vode iz krških polja jugozapadne Bosne (jugoistočni dio Glamočkog polja, jugoistočni dio Kupreškog polja, Duvanjsko polje i Livanjsko polje s Buškim blatom). Duž lijeve obale rijeke Cetine, od izvorišne zone do Trilja registrirano je nekoliko jakih krških izvora među kojima se ističu Šilovka, Kosinac, Mali i Veliki Rumin, Ruda i Grab. U kanjonskom dijelu toka nizvodno od Trilja u koritu rijeke i neposrednom zaobalju javljaju se ponori u kojima se gubi dio vode i podzemno otječe prema jakim krškim vrelima Jadra i Žrnovnice smještenim na kontaktu karbonata i vodonepropusnog fliša (Brkić i sur. 2006).
Desna obala rijeke Cetine od izvorišne zone do Trilja također ima funkciju sakupljanja oborinskih voda s istočnih padina planinskog grebena Svilaje (V. Kozjak, Svilaja) ali sliv je daleko manjeg prostranstva, pa su i pojave izvora manje i rjeđe (izvor Vrlika). Na području Sinja su to površinski dotoci vezani za područja izgrađena od vodonepropusnih klastičnih stijena. Najveći desni pritok Cetine je potok Vojskova, u koju se iznad Sinja ulijeva potok Karakašica koja se nastalja na bujični potok Sutinu. Velike visinske razlike unutar sliva Cetine iskorištene su za proizvodnju električne struje. Najviša je akumulacija Peruča u gornjem toku rijeke, a zatim akumulacije Đale i Prančevići u kanjonu nizvodno od Sinjskog polja, dok je najstarija HE Kraljevac kod Zadvarja (Brkić i sur. 2016). 


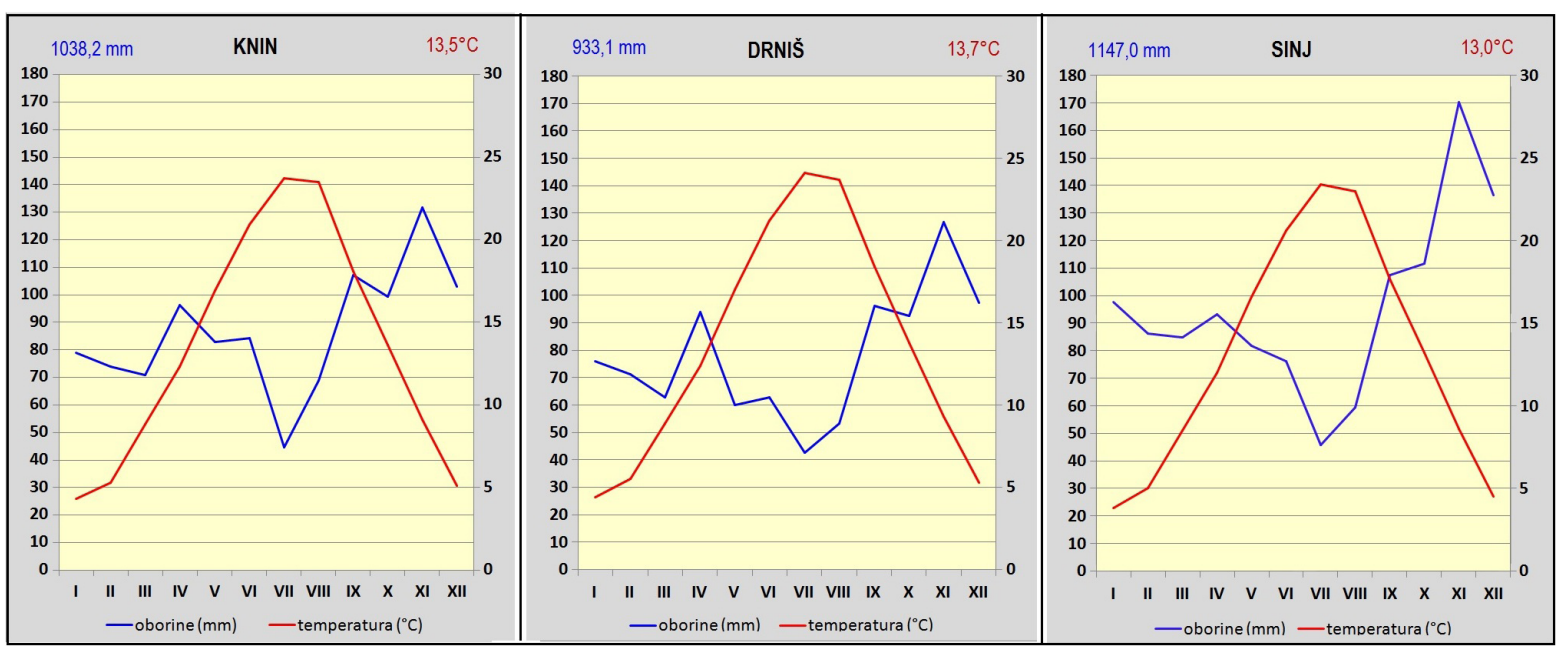

Slika 4. Klimadijagrami za Knin, Drniš i Sinj (1989. - 2018.).

\section{Klima}

Kako na Svilaji nema meteorološke postaje, za dobivanje slike o klimi šireg područja korišteni su podaci mjerenja najbližih meteoroloških postaja u Sinju, Drnišu i Kninu (sl. 4), koje su $10-20$ km udaljene od vrha Svilaje. Srednja godišnja temperatura zraka je $12,7-13{ }^{\circ} \mathrm{C}$, najhladniji mjesec je siječanj $\left(3,8-4,4^{\circ} \mathrm{C}\right)$, a najtopliji srpanj $\left(23,4-24^{\circ} \mathrm{C}\right)$. Srednja godišnja količina oborine je 933,1 - 1147 mm, najmanja u srpnju (42,7 - 45,8 mm), a najviša u studenom (126,9 - 170,2 mm). Prema tim podacima i Köppenovoj klasifikaciji klime, šire područje Svilaje ima Cfs'a tip klime. To je umjereno topla vlažna klima (bez izrazito sušnog dijela godine, ali najmanje oborina u ljetnom dijelu) s vrućim ljetom (srednja temperatura najtoplijeg mjeseca $>22{ }^{\circ} \mathrm{C}$ i četiri uzastopna mjeseca $>10^{\circ} \mathrm{C}$ ). Prema karti tipova klime u Hrvatskoj (Šegota i Filipčić 2003:35, sl. 8), uže područje Svilaje, s većim nadmorskim visinama imalo bi Cfs'b tip klime, umjereno toplu vlažnu klimu s toplim ljetom (u odnosu na Cfs'a tip klime, prosječna temperatura najtoplijeg mjeseca je $\left.<22^{\circ} \mathrm{C}\right)$.

Masiv Svilaje i Velikog Kozjaka se ističe razmjerno izoliranim položajem u odnosu na susjedne planinske lance, od kojih je odvojen krškim poljima: Kninsko, Kosovo polje (Zvjerinac), Vrličko, Petrovo polje, Dicmansko i Sinjsko polje. Sva ta krška polja su zatvorene kotline opkoljene gorskim masivima, pa zimi djeluju kao izrazita mrazišta, naročito Kninsko i Sinjsko polje. Na rubnim padinama gorskih masiva uz te kotline, javljaju se zbog toga poremećaji i inverzije zonalne vegetacije (Lovrić i sur. 1987). Tako npr. sastojine bukve nalazimo i u pojasu bjelograba, po uvalama i kotlinama na jugu Svilaje u okolici Muća (Jedlovski 1952). S druge strane, ljeti kroz te kotline mediteranski utjecaji sa sezonskom sušom prodiru sve do najviših grebena Svilaje. Zato u tim kotlinama postoje izrazite termičke amplitude s oštrim zimskim mrazovima, naročito u Sinjskom polju, s prosječno 63 dana s mrazom godišnje i apsolutnim temperaturnim minimumom do -24,2 ${ }^{\circ} \mathrm{C}$ (Kirigin i sur. 1971). Tu su, također, izrazito jaki i česti olujni vjetrovi, naročito na vršnim grebenima Svilaje i jugoistočnim padinama kod Sinja, gdje je godišnji prosjek od čak 79 dana s olujnim vjetrom preko 8 bofora. Zajedno sa Senjskim Bilom, južna Svilaja pripada najvjetrovitijim područjima u cijeloj Hrvatskoj (Lovrić i sur. 1987).

\section{Biljnogeografske značajke Svilaje}

Svilaja se nalazi unutar Ilirskog sektora Apeninskobalkanske provinicije Eurosibirske regije (RivasMartínez et al. 2004). Listopadna vegetacija u nižim visinskim zonama priključena je vegetacijskom 


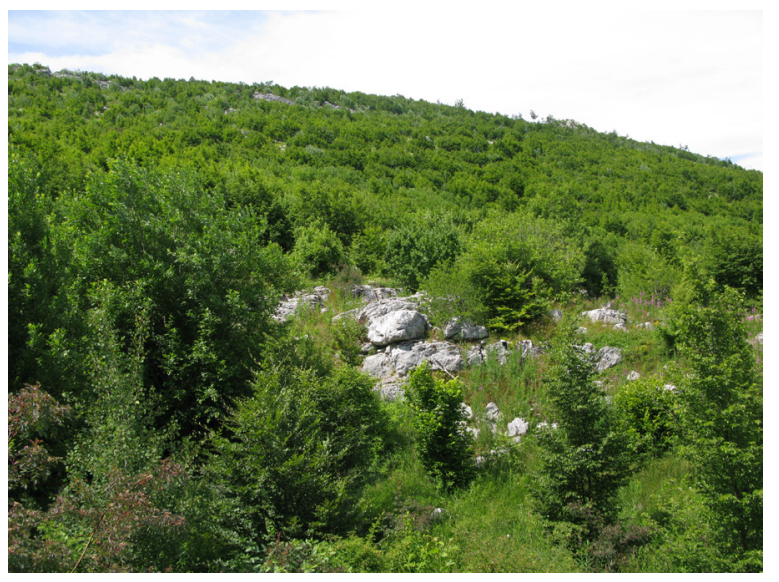

Slika 5. Primorska bukova šuma na Svilaji, u okolici Orlovih stina (foto M. Milović).

razredu termofilnih šuma listopadnih hrastova Quercetea pubescentis Doing-Kraft ex Scamoni et Passarge 1959, a u višim zonama razredu mezoflnih listopadnih i mješovitih šuma Carpino-Fagetea sylvaticae Jakucs ex Passarge 1968 (Mucina et al. 2016, Škvorc et al. 2017).

Šume medunca i bjelog graba (sveza Carpinion orientalis Horvat 1958) nalaze se na nižim obroncima do 500-600 m visine (Lovrić i sur. 1987). Najveće površine na nižim padinama Svilaje obrasle su degradacijskim stadijima tih šuma, najčešće dračicima (sveza Paliuro-Petterion P. Fukarek 1962). $\mathrm{Na}$ intenzivnije degradiranim površinama nalaze se istočnosubmediteranski suhi travnjaci (sveza Chrysopogono grylli-Koelerion splendentis Horvatić 1973; syn. Chrysopogono grylli-Saturejion subspicatae Horvat et Horvatić ex Černjavski, Grebenščikov et Pavlović 1949), među kojima prema Lovriću i sur. (1987) prevladavaju kamenjari kadulje i kovilja (asocijacija Stipo bromoidis-Salvietum officinalis Horvatić 1963).

$\mathrm{Na}$ Svilaji pojas u visinskom rasponu 500-950 m pripada zonalnim šumama medunca i crnog graba (asocijacija Seslerio autumnalis-Ostryetum carpinifoliae Horvat et Horvatić ex Horvat 1959) koje su najbolje razvijene na istočnim padinama prema Peručkom jezeru, dok su na zapadnim padinama uslijed degradacije zastupljene u obliku šikara (Lovrić i sur. 1987). Na jače degradiranim vapnenačkim podlogama dolaze pašnjaci sveze Saturejion subspicatae Tomić-Stanković 1970. Na toplijim i sunčanim zapadnim padinama Svilaje pretežu pašnjaci koji pripadaju asocijaciji Centaureo rupestris-Caricetum humilis Horvat 1931, a na hladnijim sjeveroistočnim strminama pašnjaci asocijacije Saturejo subspicatae-Edraianthetum tenuifolii Horvat in Horvat et al. 1974 (Lovrić i sur. 1987).

Na višim dijelovima Svilaje, iznad 950 m, nalazi se pojas primorske bukove šume (asocijacija Seslerio autumnalis-Fagetum sylvaticae (Horvat) M. Wraber ex Borhidi 1963) unutar sveze ilirskih neutroflnih i bazoflnih šuma bukve Aremonio-Fagion (Horvat 1950) Borhidi in Török et al. 1989. Te su bukove šume najbolje razvijene na istočnim padinama od grebena Svilaja - Jančag prema Peručkom jezeru (sl. 5), dok na degradiranim površinama, zamjenski pretežno dolaze travnjaci asocijacije Seslerio tenuifoliae-Caricetum humilis Horvat 1930 (Lovrić i sur. 1987).

Najviši grebeni Svilaje (Svilaja, Jančag) iznad 1350 $\mathrm{m}$ visine, pripadaju vegetacijskoj zoni subalpinskih šuma i šikara bukve (podsveza Saxifrago rotundifoliae-Fagenion Marinček et al. 1993). Njihovom su degradacijom na vrhu Svilaje, na izloženim kamenjarima, zastupljene kserotermne planinske rudine (sl. 6) asocijacije Carici-Seslerietum robustae Tomić-Stanković 1970, a na debljim naslagama tla u ponikvama asocijacija Festuco-Armerietum canescentis Trinajstić et Šugar 1972 (Lovrić i sur. 1987). Na našim planinama, pod utjecajem antropogene degradacije zbog dobivanja što većih površina za pašnjake, vegetacija planinskih rudina dijelom je proširena i na niže vegetacijske pojaseve sa šumskom vegetacijom (Trinajstić 1998). Pregled biljnih zajednica na Svilaji u ovom radu temelji se isključivo na literaturnim podacima, jer skoro u potpunosti podaci o njihovoj strukturi (fitocenološke tablice) ili dinamici ne postoje. Prvi zadatak u budućim istraživanjima bit će nomenklaturna validacija spomenutih asocijacija. 


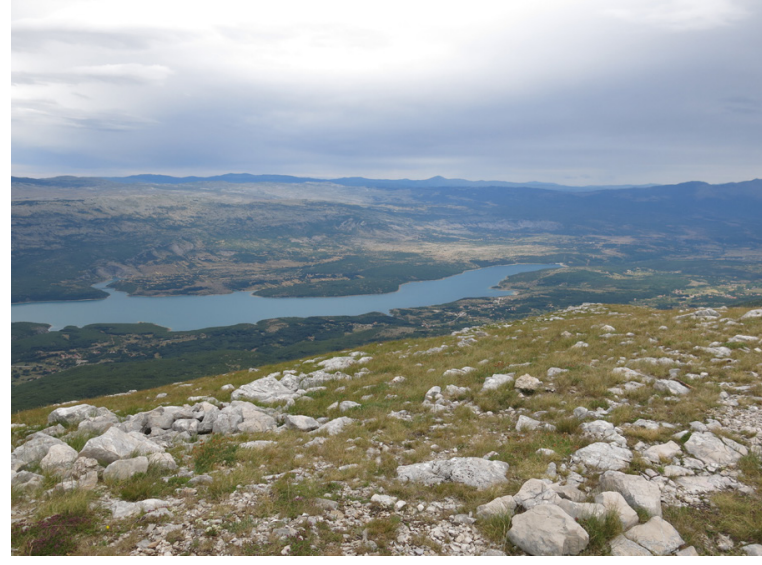

Slika 6. Pogled s najvećeg vrha na Svilaji (Bat, 1508 m) prema Peručkom jezeru (foto M. Milović).

Uz prirodne faktore, presudan utjecaj na sadašnje stanje biljnog pokrova Svilaje imao je dugotrajni utjecaj čovjeka, naročito uzgoj stoke, a u manjoj mjeri i poljodjelstvo. U 19. i u prvoj polovici 20. stoljeća, znatno su smanjene površine pod šumama, koje su iskrčene kako bi se dobio prostor za pašnjake i obradive površine. $U$ zadnjih 50 godina, dolazi do obrnutog trenda, jer zbog iseljavanja stanovništva i smanjenog intenziteta ispaše dolazi do zaraštavanja napuštenih kultura i pašnjaka u šikare i šume (Durbešić i Fuerst-Bjeliš 2016). Površine pod šikarama i šumama vijerojatno bi bile znatno veće da u posljednjih 20 godina nije bilo nekoliko većih požara čije je gašenje bilo otežano ili onemogućeno, jer su dijelovi Svilaje nakon Domovinskog rata još uvijek onečišćeni minama ili se tretiraju kao minski sumnjiva područja (Durbešić i Fuerst-Bjeliš 2016).

\section{Zaštićena područja i vrste}

Uredbom o ekološkoj mreži (NN 124/13, NN 105/15), Svilaja je uvrštena u Ekološku mrežu NATURA 2000 u Republici Hrvatskoj (HR 2000922 Svilaja) kao područje značajno za vrste i stanišne tipove (sl. 7). Ciljane vrste su vuk (Canis lupus L.), leptir dalmatinski okaš (Proterebia afra Fabricius ssp. dalmata Godart) i modra sasa (Pulsatilla grandis Wender.), a ciljana staništa ilirske bukove šume [Aremonio-Fagion (Horvat 1950) Borhidi in Törek et al. 1989, NATURA 91K0, NKS E.4.6.], istočno submediteranski suhi travnjaci (Scorzoneretalia

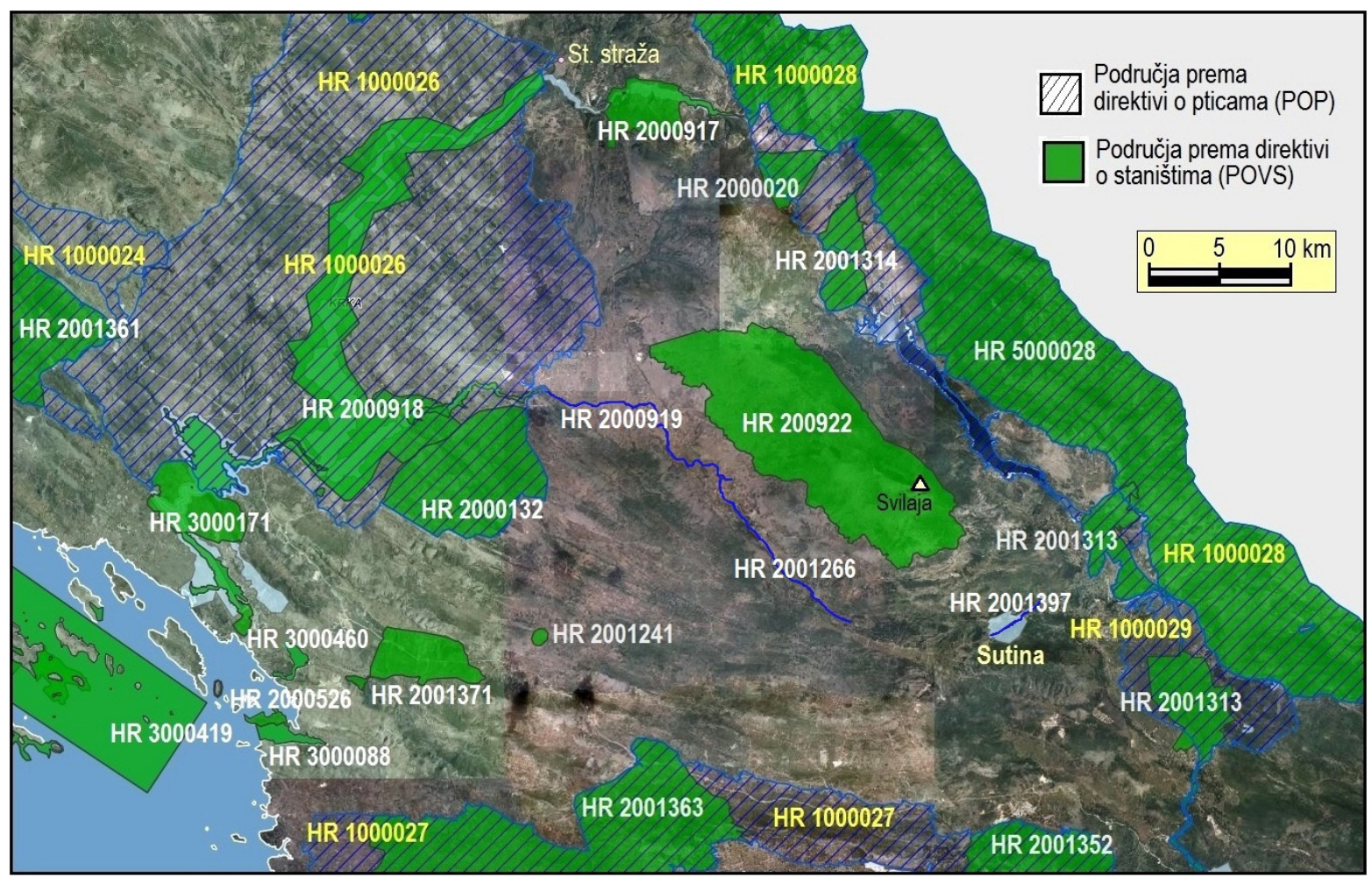

Slika 7. NATURA 2000 područja na Svilaji i okolici (Bioportal HAOP, http://www.bioportal.hr/gis/). 
villosae Kovačević 1959, NATURA 62A0, NKS C.3.5.) te špilje i jame zatvorene za javnost (NATURA 8310). Kanjonski dio toka bujičnog potoka Sutine (pritoka Cetine), na južnim padinama Svilaje (sl. 7), proglašen je 2001. značajnim krajobrazom, među ostalim i zbog sastojina bukve koja zbog temperaturne inverzije tamo dolazI u pojasu hrastovih šuma. Kroz zaštićeni krajobraz protiče potok Sutina koji je 2015. proglašen dijelom ekološke mreže (HR 2001397) s ciljem očuvanja bjelonogoga raka (Austropotamobius pallipes Lereboullet, 1858).

U ekološku mrežu NATURA 2000 uvrštena su područja rijeke Čikole (HR 2000919) koja izvire u Mirlović Polju na jugozapadnim padinama Svilaje i njene pritoke Vrbe (HR 2001266). Ciljane vrste u Čikoli su endemične ribe, oštrulj (Aulopyge huegelii Heckel, 1842) i više svojti iz roda gaovica (Phoxinellus sp.), a Vrba je važno stanište za očuvanje uklive (Telestes turskyi Heckel, 1843) i dalmatinske gaovice (Phoxinellus dalmaticus Zupančič \& Bogutskaya, 2000). Procjenjuje se da u Čikoli i Vrbi živi najveći dio ukupne hrvatske populacije dalmatinske gaovice (50-60\%).

\section{Pregled dosadašnjih istraživanja flore i vegetacije}

Prvi navod biljne svojte iz skupine vaskularnih biljaka za područje Svilaje potječe s početka 19. stoljeća. Roberto Visiani u radu Ogled dalmatinskog bilja („Stirpium Dalmaticarum specimen“), navodi božur pod imenom Paeonia officinalis, za planine u blizini Vrlike (Visiani 1826:42, in montibus prope Verlika). Kasnije, u drugom volumenu djela Flora Dalmatica, autor za Dalmaciju navodi samo planinski božur pod imenom P. corallina Retz. (= P. mascula (L.) Miller), s nalazištima Velebit i Snježnica, ne spominjući Vrliku ni Svilaju (Visiani 1852:75). Zbog toga nalaz planinskog božura za Svilaju (okolicu Vrlike) ostaje dvojben.

U prikazu flore šireg područja Splita, Petter (1832) navodi ukupno 1037 svojti biljaka, među kojima je i 19 svojti za koje kao nalazište navodi Vrliku
(Verlika): Anthyllis vulneraria L. (N. 80, str. 11), Bryonia dioica Jacq. (N.163, str. 22), Chelidonium majus L. (N. 243, str. 34), Conium maculatum L. (N. 276, str 39), Fragaria vesca L. (N. 416, str. 58), Geranium sanguineum L. (N. 448, str. 62), Helleborus multifidus Vis. (N. 468, str. 65), Orchis coriophora (N. 650, str. 90), Silene conica (N. 875, str. 120), Verbascum nigrum (N. 994, str. 137), itd.

U jesen 1844., Antonio Mazzoleni je posjetio Svilaju, tijekom obilaska nekih dalmatinskih i hercegovačkih planina: Velebita, Dinare, Koma, Gnjata i Prologa (Clementi 2017:177). Mazzoleni, porijeklom iz ugledne šibenske obitelji, studira medicinu u Padovi, a poseban interes pokazuje za Visijanijeva predavanja iz botanike. Sakupljene biljke dostavio je Visijaniju, a zapažanja s putovanja objavio je u kratkom članku u kojem, usputno donosi i kraće popise pronađenih biljaka, ali ne navodi biljke sa Svilaje (Mazzoleni 1845). Zanimljivo je da Lovrić i sur. (1987), u kratkom osvrtu na prethodna istraživanja pogrešno navode taj Mazzolenijev rad kao važan prilog flori Svilaje.

Najveći doprinos flori Svilaje u 19. stoljeću dao je Roberto Visiani. Kako je u razdoblju 1830. - 1835. službovao kao liječnik u Drnišu, bio je u prilici dobro proučiti floru šireg šibenskog

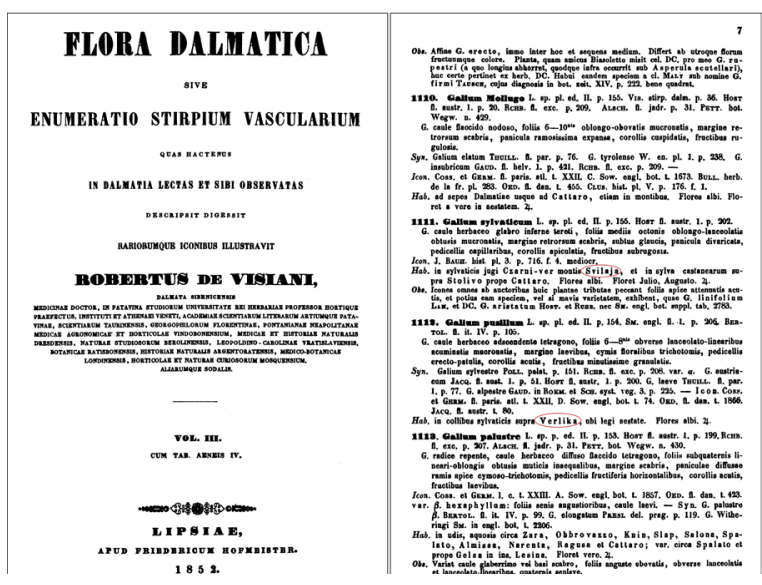

Slika 8. Naslovna stranica djela Flora Dalmatica (III vol.) i sedma (7.) stranica na kojoj se navodi Svilaja kao nalazište vrste Galium sylvaticum L., a Vrlika za vrstu G. pussillum L. 
i drniškog područja, pa tako i Svilaje. U djelu Flora Dalmatica (Visiani 1842-1852) navodi čak 104 svojte s područja Svilaje (sl. 8), među kojim su i neke rijetke i endemične svojte: Acanthus balcanicus Heywood et I. Richardson (1847:226, kao A. longifolius Host), Carlina acanthifolia All. (1847:80), Crocus biflorus Mill. ssp. weldenii (Hoppe et Fürnr.) K. Richt. (1842:119, kao C. biflorus Mill.), Cruciata pedemontana (Belliard) Ehrend. (1852:9 kao Galium pedemontanum All.), Lamium bifidum Cirillo (1847:211), Lilium martagon L. (1842:132), Melampyrum cristatum L. (1847:178), Pedicularis friderici-augusti Tomm. (1847:176), Peucedanum longifolium Waldst. et Kit. (1852:51), Thymus bracteosus Vis. ex Benth. (1847:193), Tulipa sylvestris L. (1842:133), itd. Kao nalazišta navodi planinu Svilaju ili uže lokalitete s tog područja: Vrlika (Verlika), Lemeš (Lemess), Muć (Much), Ogorje (Ogorie), Miočić (Miocich) i Maovice (Mavize). U djelu Flora Dalmatica (1842-1852), Visiani donosi i opise novih vrsta za znanost, među kojima su i dvije svojte čije je klasično nalazište (,locus classicus“) na području Svilaje. Prva je vrsta Centaurea tuberosa Vis. (,in montosis sylvaticis Miocich, et Mavize inter Dernis, et Verlika, ..."), koja u suvremenoj taksonomskoj literaturi ima status podvrste C. napulifera Roch. ssp. tuberosa (Vis.) Dostál (sl. 9). Pod imenom

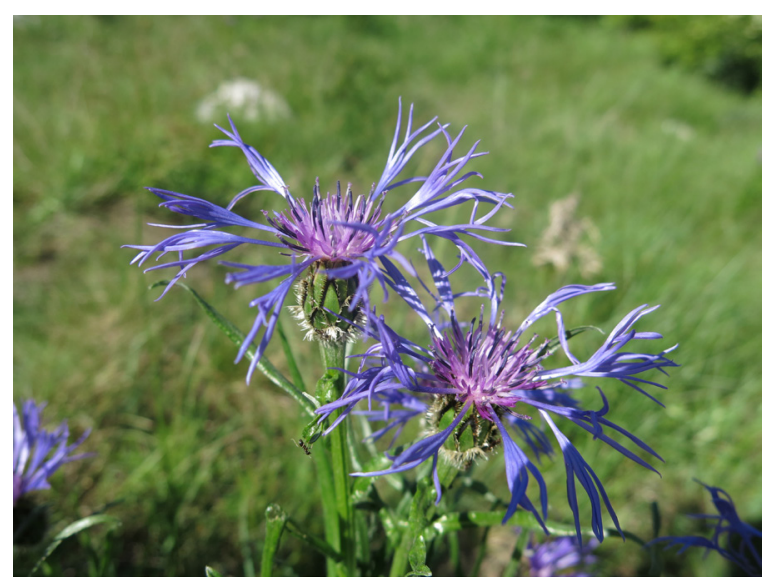

Slika 9. Gomoljastu zečinu (Centaurea napulifera ssp. tuberosa) je kao novu svojtu za znanost prvi opisao Visiani (1847:33, kao C. tuberosa), navodeći Miočić i Maovice na Svilaji kao klasično nalazište (foto M. Milović).
Chaerophyllum laevigatum, Visiani je opisao novu vrstu za znanost s klasičnim nalazištem iz okolice Vrlike i Maovica (1842:65, ,in umbrosis circa Verlika et Mavicze"). Naknadno je utvrđeno da se radi o ranije već opisanoj vrsti pod imenom Ch. bulbosum L. U naknadno objavljenom Suplementumu, Visiani navodi Svilaju kao nalazište za vrstu Sisimbryum irio L. (1872:123, in devexitatibus montis Svilaja).

Josip Schlosser i Ljudevit Vukotinović (1869), autori djela Flora Croatica, prve cjelovite flore Hrvatske u tadašnjim granicama, ne navode nova nalazišta biljnih vrsta s područja Dalmacije, nego preuzimaju već poznate lokalitete iz Visijanijeva djela Flora Dalmatica, uključivši i one sa Svilaje.

U organizaciji Prirodoslovnog društva Sveučilišta u Beču, provedeno je u ljeto 1907. istraživanje flore Dinarskih planina i Velebita, u sklopu kojega su Erwin Janchen i Bruno Watzl, posjetili Svilaju. Popis pronađenih biljaka objavili su u više članaka u časopisu Österreichische Botanische Zeitschrift u suradnji s čuvenim mađarskim botaničarom Arpadom Degenom (Janchen \& Watzl 1908). Rezultate s te botaničke ekskurzije objavio je i Janchen (1908) u posebnom radu u kojem među ostalim navodi približno 30 biljaka sa Svilaje: Acer obtusatum Willd., Amelanchier ovalis Medik., Arabis scopoliana Boiss., Cerastium grandiflorum Waldst. et Kit., Crepis chondrilloides Jacq., Fagus sylvatica L., Lactuca perennis L., Onosma stellulata Waldst. et Kit., Pedicularis comosa L., Ranunculus carinthiacus Hoppe, Rhamnus alpinus L. ssp. fallax (Boiss.) Maire et Petitm. (kao $R h$. fallax), Sedum atratum L., Silene saxifraga L., Spiraea media Schmidt, itd. U monografiji o rodu Edraianthus, isti autor navodi Svilaju kao jedno od nalazišta za vrste E. graminifolius (Waldst. et Kit.) A.DC. i E. tenuifolius (L.) A.DC. (Janchen 1910).

Dragutin Hirc boravio je 1905. i 1907. na širem šibenskom području, ali nije istraživao floru Svilaje (Hirc 1909). U djelu Reviziji hrvatskeflore, Hirc (1903-1912), ne navodi nove nalaze za Svilaju. Za neke svojte koje su već Visiani (1842-1852) i Janchen (1908) zabilježili za Svilaju, daje kritički osvrt, dopunjava sinonime 
ili samo ponavlja prethodno zabilježena nalazišta (Hirc 1906, 1908, 1910, 1912). Tako npr. za svojtu Anchusa microcalyx Vis., koju Visiani spominje za Vrliku (1847:252), Hirc navodi da je već Neilreich upozorio da je riječ o uskolisnoj i sitnocvjetnoj formi vrste A. officinalis L. (Hirc 1906:73).

U nekoliko radova o vegetaciji Hrvatske s početka i sredinom 20. st., autori navode pojedinačne vrste ili zajednice s područja Svilaje. Tako npr., u prikazu flore i vegetacije Dalmacije, Lujo Adamović navodi svojtu Tulipa grisebachiana Pant. u sastavu vegetacije vapnenačkih stijena na Svilaji (Adamović 1911:62), a za okolicu Vrlike sađene šume crnoga bora (Pinus nigra Arnold) (Adamović 1929:48).

Ivo Horvat, naš poznati fitocenolog i najbolji poznavalac planinske flore i vegetacije Hrvatske, u svojim radovima ne navodi biljne vrste i vegetacijske snimke sa Svilaje (Horvat 1930, 1931, 1938, 1962). Pri istraživanju vegetacije Dinarskih planina tijekom srpnja i kolovoza 1930., Horvat je u nekoliko navrata prošao kroz Vrliku, ali ne navodi biljke s tog područja (Horvat 1932). U prikazu vegetacije jugoistočne Europe, Horvat et al. (1974), navode Svilaju kao jedan od lokaliteta na kojem dolazi endemična svojta Astragalus monspessulanus L. ssp. illyricus (Bernhardt) Chater.

Dušan Jedlovski (1952) navodi nalaz bukove šume na dva lokaliteta na jugozapadnim padinama Svilaje, u pojasu medunca i graba. Prvi je uz bujični potok Sutina, a drugi na lokalitetu Duboka draga u blizini Gornjeg Ogorja. Jedlowski navodi da je te bukove šume u svibnju 1950. proučavao Ivo Horvat, a analiza sastava je pokazala da se ne radi o zajednici primorske bukove šume, već samo o posebnoj varijanti zajednice hrasta medunca i bjelograba u kojoj dominira bukva (Jedlovski 1952:162). Sastojine bukve javljaju se na tim lokalitetima zbog specifičnih mikroklimatskih prilika uvjetovanih temperaturnom inverzijom.

U pregledu vegetacije primorskog pojasa Hrvatske, Stjepan Horvatić koristi i snimke iz šire okolice Muća, s južnih padina Svilaje, za prikaz sastava travnjaka primorskog zečjeg trna Ononido antiquorum-Brometum condensati Horvatić (1934) 1963 (Horvatić 1963:85).

U sklopu fitocenoloških istraživanja ruderalne vegetacije Hrvatske, u lipnju 1961. Ljerka Marković dolazi u Vrliku gdje bilježi dvije asocijacije: Lolio perennis-Plantaginetum majoris Beger 1930 (Marković 1964:200, tab. XXIV, snimke 36 i 37) i Alliario petiolatae-Chaerophylletum temuli Lohmeyer 1955 (Marković 1964:147, tab. XVI, snimka 11). Snimke zajednica iz Vrlike, autorica koristi kasnije u radu o ruderalnoj vegetaciji kontinentalnih dijelova Hrvatske (Marković-Gospodarić 1965). U posebnom prikazu sveze Geo urbani-Alliarion officinalis u Hrvatskoj (Marković 1992), autorica koristi snimku zajednice Alliario petiolatae-Chaerophylletum temuli iz Vrlike u čijem sastavu navodi 16 svojti među kojima su: Artemisia vulgaris L., Bromus sterilis L., Euphorbia helioscopia L., Galium aparine L., G. mollugo L., Plantago lanceolata L., Medicago lupulina L., Tordylium maximum L., itd.

U analizi biljnog pokrova Biokova, Fran Kušan (1969) za vrste Tulipa sylvestris L. i Lilium cattaniae Vis. među nalazištima spominje i ona otprije poznata sa Svilaje. Kušan smatra da Visijanijevi nalazi vrste Lilium martagon L. za Dalmaciju (Visiani 1842:132) pripadaju vrsti L. cattaniae Vis. (Kušan 1969:178), koju taksonomi u novije vrijeme tretiraju kao podvrstu, L. martagon L. ssp. cattaniae (Vis.) Degen (Nikolić 2019). Nalaz te svojte za Svilaju potvrđuje i Ljerka Regula-Bevilacqua (1985-1986).

Na jugozapadnim padinama Svilaje 30-tih godina 20 st. sađene su kulture crnog i primorskog bora kao prevencija bujičnoj eroziji tla (Durbešić i FuerstBjeliš 2016). U sklopu istraživanja rasta primorskog bora (Pinus pinaster Aiton) na području Hrvatske, među ostalim, istraživana je i kultura podignuta na području naselja Sutina, u okolici zaseoka Đipalo (Šumarija Sinj), u zoni šuma bjelograba i medunca (Meštrović 1972). U sastojini primorskog bora u okolici sela Đipalo, autor Šime Meštrović navodi i druge vrste: Juniperus oxycedrus L., Fraxinus ornus L., 
Quercus pubescens Willd. (kao Q. lanuginosa Thuill.), Ostrya carpinifolia Scop., Carpinus orientalis Mill. i dr.

Zajednica kamenjara uspravnog ovsika i isprekidane šašike (Bromo erecti-Seslerietum interruptae Trinajstić ex Terzi 2011), prvi put je opisana s otoka Krka. Prilikom vegetacijskog kartiranja Hrvatske 70-tih godina 20. stoljeća, otkrivena je i na Velebitu, Dinari i Svilaji (Trinajstić 1987).

Pri sintaksonomskoj analizi kamenjarskih pašnjaka sjajne smilice i ilirske vlasulje (Koelerio splendentis-Festucetum illyricae Horvatić 1963 corr. Trinajstić 1992), Ivo Trinajstić navodi i jednu fitocenološku snimku s 40 svojti s područja Muća (Trinajstić 1992, tab. 1).

U širem istraživanju flore i vegetacije primorskih Dinarida, Andrija Željko Lovrić i Mladen Rac su među ostalim istraživali i planinski lanac Svilaje, tj. Svilaju s Velikim Kozjakom (Lovrić i Rac 1987, 1989, 2005, Lovrić i sur. 1987, 1989). U prilogu fitogeografiji Svilaje i Velikog Kozjaka, Lovrić i sur. (1987), navode visinsku raspodjelu vegetacije te za to područje navode tridesetak biljnih zajednica. Posebno izdvajaju 51 svojtu iz skupine „značajnih, rijetkih i endemskih taksona“, među kojima su mnoge taksonomski dvojbenog statusa: Corylus pontica Koch., Pteridium tauricum Grosg., Quercus brachyphylla Kotschy, Sedum dinaricum M.G., itd. Autori zaključuju da je po sastavu vegetacije Svilaja sličnija kontinentalnim padinama udaljenijeg Biokova nego znatno bližih masiva Dinare i južnog Velebita (Lovrić i sur. 1987:201). U prikazu visokoplaninske vegetacije najhladnijih vrhova na južnim primorskim Dinaridima, isti autori (Lovrić i Rac 1989) navode više asocijacija za Svilaju: na olujnim kamenjarama vršnih dijelova (MinuartioSaxifragetum coriophyllae (Horvat 1942) Kušan 1969, Minuartio capillaceae-Genistetum pulchellae Šegulja et Bedalov ex Terzi 2011) u snježnim ponikvama (Narcisso-Gentianetum nivalis Lovrić et Rac 1988) te u bazofilnim cretovima (Blysmo compressi-Juncetum thomasii Quézel 1964). Lovrić i sur. (1989) uz opću zonaciju planinskog lanca Svilaje posebno ističu raznolikost vegetacije planinskih travnjaka, koji su zbog čestih olujnih vjetrova i dolomitne podloge znatno sušniji od travnjaka na susjednim planinama. Kako Lovrić u svojim radovima pri navođenju vrsta i zajednica uglavnom koristi naziv „planinski lanac Svilaje“, nije moguće odrediti je li se pojedini nalazi odnose isključivo na Svilaju, odnosno samo na Veliki Kozjak, ili se pak odnose na obe planine.

U organizaciji Prirodoslovnog muzeja u Splitu je organizirana izložba fotografija orhideja (por. Orchidaceae) koje rastu na području od Kaštela, preko Kozjaka do Svilaje. Autor izložbe Vladimir Golubić u katalogu navodi popis od 36 svojti od kojih za 30 kao nalazište navodi lokalitete sa Svilaje (Golubić 1999). Od lokaliteta na Svilaji autor posebno ističe lokalitet Šegovića brig u okolici Muća, na kojem je pronađeno čak 15 svojti orhideja.

Radovan Kranjčev je u više navrata posjetio područje Svilaje, a zapažanja je objavio u više stručnih članaka i u monografiji o hrvatskim orhidejama (Kranjčev 2005). U članku u kojem opisuje dojmove za boravka na jugozapadnim padinama Svilaje navodi i nekoliko biljnih vrsta: Chamaespartium sagittale (L.) Gibbs (kao Genista sagittalis), Haplophyllum patavinum (L.) G.Don, Legousia speculum-veneris (L.) Chaix, Stippa pennata L., itd. (Kranjčev 2002). Na području Zelova (južne padine Svilaje), isti autor pronalazi veliku populaciju bosanskog ljiljana, Lilium bosniacum (Beck) Beck ex Fritsch (Kranjčev 2006). Svojta je dvobenog taksonomskog statusa jer je neki autori smatraju zasebnom vrstom (Goaverts 2019, Muratović i dr. 2005), a drugi podvrstom ili samo varijacijom tipičnog kranjskog ljiljana $L$. carniolicum Bernh. ex Koch (Nikolić i sur. 2015). U opširnoj monografiji o hrvatskim orhidejama, Kranjčev (2005) ističe širu okolicu sela Muć i jugozapadne padine Svilaje (do nadmorske visine oko $800 \mathrm{~m}$ ), kao jedno od najbogatijih nalazišta orhideja u Hrvatskoj. Neke od zabilježenih svojti orhideja su: Dactylorhiza maculata (L.) Soó, Gymnadenia conopsea (L.) R. Br., Listera ovata (L.) R. Br., Ophrys apifera Huds., O. dinarica Kranjčev et P. Delforge (kao O. fuciflora ssp. dinarica R. Kranjčev), O. tetraloniae W. P. Teschner, Orchis militaris L., O. 
morio L., O. tridentata Scop., Platanthera chlorantha (Custer) Rchb., itd. Neke svojte koje za lokalitete na Svilaji navodi Kranjčev dvojbenog su taksonomskog statusa pa nisu uvrštene u bazu podataka Flora Hrvatske (npr. Ophrys corniculata Kranjčev).

Na području Neorića, uz južne padine Svilaje, Nediljko Ževrnja i Dalibor Vladović (2005) pronalaze dvije svojte šafrana - Crocus tommasinianus Herbert. i C. weldenii Hoppe et Fürnrohr. Druga svojta je na nalazištu bila zastupljena sa sve tri poznate forme: f. weldenii, f. bicolor Pavletić Zi. et Trinajstić, te f. lutescens Pulević). Iako se područje Neorića nalazi izvan granica istraživanog područja, nalaze navedenih svojti spominjemo zbog mogućnosti da one dolaze i na južnim padinama Svilaje, sjevernije od Neorića, što treba dodatno istražiti.

U prikazu rezultata preliminarnih istraživanja flore Svilaje, Milenko Milović i sur. (2013), također ukazuju na bogatu orhidejsku floru Svilaje te navode veći broj broj endema i ugroženih svojti. Posebno ističu nalaze nekih proljetnica: Anemone nemorosa L., Corydalis solida (L.) Swartz, Erythronium dens-canis L., Hyacinthella dalmatica (Baker) Chouard, Narcissus radiiflorus Salisb., Pulsatilla grandis Wender., Tulipa sylvestris L., itd.

U cjelovitom pregledu šumskih tipova i šumskih zajednica u Hrvatskoj, Joso Vukelić i sur. (2008), za primorsku bukovu šumu s jesenskom šašikom (NKS E.4.6.3., asocijacija Seslerio autumnalis-Fagetum M. Wraber ex Borhidi 1963) izdvajaju sedam lokaliteta među kojima je i područje Samara, sjeverozapadno od vrha Svilaje. Odabrani su lokaliteti s najvećim stupnjem reprezentativnosti i očuvanosti ovoga stanišnog tipa, pa su na prijedlog autora uvršteni u Nacionalnu ekološku mrežu (NEM), odnosno ekološku mrežu Europske unije NATURA 2000 (Vukelić i dr. 2008:137). Kako nemamo podataka o provedenim fitocenološkim snimkama, nije moguće sa sigurnošću utvrditi koje sve vrste iz reprezentativnog sastava primorske bukove šume, dolaze u bukovim šumama na području Samara na Svilaji.
U sklopu šireg istraživanja rasprostranjenosti endemične svojte leptira Proterebia afra dalmata (Godart 1824), Antun Delić (2010) pronalazi desetak novih nalazišta na jugozapadnim padinama Svilaje, u široj okolici Crivca i Pribuda. Autor navodi i nekoliko biljnih svojti kojima se taj leptir hrani: Thymus sp., Veronica austriaca L. ssp. austriaca [kao V. austriaca ssp. dentata (F. W. Schmidt) Watzl] i Crepis rubra L. te travu Bromus erectus Huds. ssp. condensatus (Hack.) Asch. et Graebn. (kao B. condensatus Hack.) na koju polaže jajašca.

Dalibor Vladović i sur. (2012) za okolicu jame Velika Golubinka (istočno od naselja Milešina) navode 37 svojti među kojima i ilirsko-jadranski endem Vicia ochroleuca Ten. ssp. dinara (K. Malý) Rohlena.

Anamarija Durbešić i Borna Fuerst-Bjeliš (2016) analiziraju trendove promjena u pejzažu na širem području Ogorja (južne padine Svilaje), na temelju promjena biljnog pokrova, za početno (1830. 1846.), prijelazno (1975.) i današnje razdoblje (2010. - 2023.). U promatranom razdoblju od gotovo 200 godina, autori kao dominantni trend promjena izdvajaju značajno smanjenje površina pod pašnjacima, poljoprivrednim kulturama i šumama, a povećanje površina pod šikarama. Listopadne šikare, koje početkom 19. stoljeća gotovo da i nisu bile zastupljene, danas zauzimaju gotovo polovicu površine cjelokupnog područja Ogorja. Autori zaključuju da su utvrđeni trendovi promjene pejzaža posljedica iseljavanja stanovništva iz ruralnih krajeva Zagore u obalne gradove gdje se zapošljavaju u industriji i turizmu (proces litoralizacije). Napuštanje tradicijskog načina života temeljenog na stočarstvu i ratarstvu u lokaliziranim plodnijim zonama tog krškog područja Zagore rezultiralo je promjenama u vegetacijskom pokrovu (zaraštavanje pašnjaka i napuštenih poljoprivrednih površina u šikare), odnosno promjenama u pejzažu (Durbešić i Fuerst-Bjeliš 2016).

Ankica Čović (2017) u svom magistarskom radu o florističkim i meliorativnim značajkama kultura crnog bora (Pinus nigra Arnold), među ostalim, analizira i floristički sastav kultura crnog bora 
različite starosti na području Gospodarske jedinice Borovača (Šumarija Split) koja se nalazi na jugozapadnim padinama Svilaje, na području Donjeg Muća. Te šume su intenzivno sađene sredinom 20. stoljeća kako bi se suzbila bujična erozija tla.

U vegetaciji zidova, u centru naselja Vrlika i u zidinama tvrđave Prozor iznad Vrlike, pronađena je stenoendemična vrsta Arenaria orbicularis Vis. (Milovići Karađole 2016). Ta vrsta je prije toga nalaza bila poznata samo iz donjeg kanjona Paklenice te iz kanjona Zrmanje u okolici Obrovca. U zidinama Prozora zabilježena je populacija od oko 500 jedinki. Od ostalih vrsta zabilježene su: Asplenium ceterach L., A. ruta-muraria L., A. trichomanes L., Dasypyrum villosum (L.) P. Candargy, Galium lucidum All., Geranium purpureum Vill., G. rotundifolium L., Inula verbascifolia (Willd.) Hausskn. ssp. verbascifolia, Micromeria juliana (L.) Benth. ex Rchb., Parietaria judaica L., Pistacia terebinthus L., Satureja montana L., itd. (Jasprica i sur. 2020).

U sklopu revizije roda Fritillaria (Liliaceae) u Hrvatskoj, Radovan Kranjčev i Damir Šešok (2016) provode opsežna terenska istraživanja tijekom kojih su posjetili i Svilaju. Svojtu Fritillaria messanensis Raf. ssp. neglecta (Parl.) Nyman su pronašli u okolici Orlovih stina, a za F. montana Hoppe ex W.D.J.Koch navode tri nalazišta, u okolici prijevoja Lemeš (Gornje Maovice), na području Zelova i Orlovih stina.

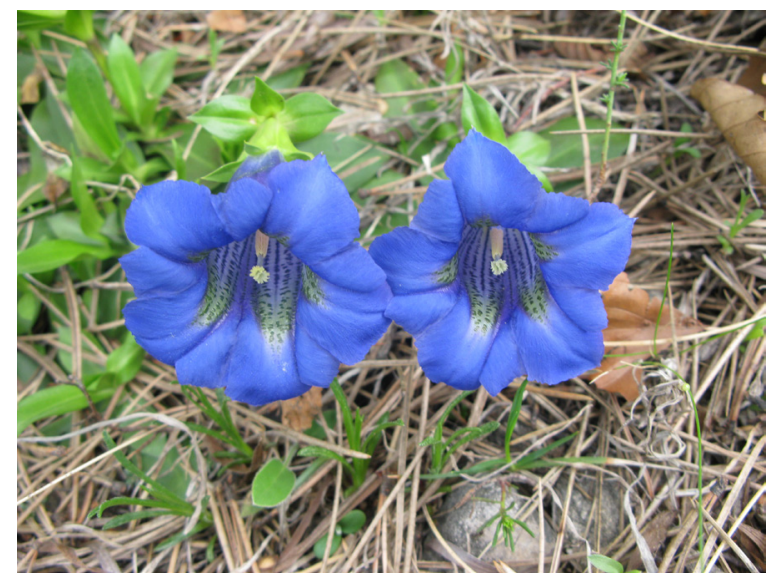

Slika 10. Dinarska sirištara (Gentiana dinarica Beck), endemična vrsta koja raste na Svilaji, u okolici Orlovih stina (foto M. Milović).
$\mathrm{U}$ analizi rasprostranjenosti vrste Matthiola fruticulosa (L.) Maire u Hrvatskoj, Vedran Šegota i sur. (1916) navode i tri nova nalazišta na Svilaji, na području između Gornjeg Ogorja i Orlovih stina. Biljka raste na vapnenačkoj, blago nagnutoj i sipinastoj podlozi, zajedno s vrstama: Cephalaria leucantha (L.) Roem. et Schult., Edraianthus tenuifolius (Waldst. et Kit.) A.DC., Fumana procumbens (Dunal) Gren. et Godr., Globularia cordifolia L. ssp. bellidifolia (Ten.) Wettst., Helichrysum italicum (Roth) G.Don, Inula ensifolia L., Satureja subspicata Vis., Jurinea mollis (L.) Rchb., Anthyllis vulneraria L. ssp. praepropera (A.Kern.) Bornm., itd. Do sada je ova rijetka vrsta naše flore bila poznata jedino s Pelješca, dok nalazi iz 19. stoljeća za okolicu Dubrovnika u novije vrijeme nisu potvrđeni.

Vedran Šegota (2016) je prezentirao rezultate istraživanja proljetne flore južnih padina planine Svilaje. Od zabilježenih svojti autor posebno izdvaja nalaze nekih rijetkih biljaka: Chouardia lakusicii (Šilić) Speta, Gentiana dinarica Beck (sl. 10), G. cruciata L., Platanthera bifolia (L.) Rich, Coeloglossum viride (L.), Crocus biflorus Mill. ssp. weldenii i Orthilia secunda (L.) House.

Nedavno su objavljeni rezultati istraživanja bioraznolikosti područja Zaštićenog krajobraza „Sutina“ (Vladović i sur. 2019), među kojima se navodi i popis vaskularne flore koji sadrži 529 svojti. Područje ZK „Sutina“ uz južne padine Svilaje obuhvaća i područje brda Visošnica (941 m), koja je izvan granica istraživanog područja. Kako autori ne navode preciznija nalazišta unutar zaštićenog područja, nije moguće utvrditi koje su svojte $\mathrm{s}$ tog popisa pronađene na lokalitetima na Svilaji, a koje na Visošnici.

Osim podataka objavljenih u različitim radovima, posebnu važnost za poznavanje flore Svilaje imaju herbarijski primjerci pohranjeni u stranim i domaćim herbarijima. U multidisciplinarnoj analizi života i djela Roberta Visianija, Moreno Clementi (2017), među ostalim, analizira herbarijske primjerke u njegovu herbariju u Padovi (Herbarium Dalmaticum) prema nalazištima. Herbar sadrži 
značajan broj biljaka sa šireg šibenskog područja i planine Svilaje (Clementi 2017:sl. 17). Autor zaključuje da su, u velikoj većini, nalazišta u djelima Visianija $(1826,1842-1852,1872)$ navedena na temelju herbarijskih primjeraka biljaka sakupljenih s tih lokaliteta. Kako se lokaliteti sa Svilaje u djelu Flora Dalmatica spominju kao nalazišta uz 105 biljnih svojti, za pretpostaviti je da se najmanje toliko herbarijskih primjeraka sa Svilaje nalazi u Visianijevu herbaru u Padovi. Kako su mnogi europski botaničari i sakupljači bilja boravili na području Dalmacije, a neki od njih i na Svilaji (Janchen 1908), za pretpostaviti je da se u nekim europskim herbarijima, naročito onom u Beču, nalaze primjerci sakupljeni na području Svilaje.

Kako je iz pregleda florističkih istraživanja vidljivo da je, nakon Visianija, samo nekolicina domaćih botaničara posjetila Svilaju, očekivano je samo nekoliko biljaka s tog područja pohranjeno u domaćim herbarijima (Nikolić 2019). Tako su u herbariju Prirodoslovnog muzeja u Zagrebu, pohranjeni još nedeterminirani primjerci roda Festuca i Edraianthus koje je u jesen 1966. sakupio Ivo Trinajstić te još nekoliko primjeraka koje su na Svilaji sakupile Suzana Buzjak i Zorana Sedlar za vrijeme botaničke ekskurzije u organizaciji Hrvatskog botaničkog društva (Vrbek i Buzjak 2019). Kako je digitalizacija primjeraka u Herbariju ZA tek u začecima, nije poznato koliko je u njemu primjeraka sa Svilaje. Za sada je poznato tek nekoliko primjeraka (Nikolić 2019): Xanthium spinosum L. (Lj. Marković, 8.6. 1961., Vrlika), Fritilaria montana Hoope (V. Šegota, 26. 4. 2010., Svilaja, Gornje Ogorje) i Dianthus sylvestris Wulfen in Jacq. ssp. tergestinus (Rchb.) Hayek (S. Bogdanović i I. Ljubičić, 1. 7. 2018., Svilaja, Orlove stine).

\section{Zaključci}

Iz navedenog pregleda, može se zaključiti da do sada nije bilo sustavnog istraživanja flore Svilaje. Nakon Visianija, od sredine 19. stoljeća do danas, kroz vremensko razdoblje od gotovo 170 godina, objavljivani su samo pojedinačni nalazi biljaka, kraće florne liste i izdvojene fitocenološke snimke ili pak samo taksativni navodi o prisutnosti asocijacija bez popratnih snimki, nastali kao rezultat povremenih i usputnih posjeta botaničara. Vegetacija Svilaje s detaljnim poznavanjem strukture i florističkog sastava biljnih zajednica tj. temeljena na fitocenološkim snimkama, u potpunosti je nepoznata. Točan broj zabilježenih biljnih svojti nije moguće precizno utvrditi zbog razlika u shvaćanju granica Svilaje i nepreciznom navođenju lokaliteta u prethodno objavljenim radovima. Kritičkom analizom publiciranih podataka, za lokalitete na Svilaji u granicama kako je to promatrano u ovom radu, utvrđeno je približno 700 svojti vaskularnih biljaka.

Snažna depopulacija, smanjivanje intenziteta tradicionalnog stočarstva i poljodjelstva te brojni požari, u značajnoj su mjeri utjecali na današnje stanje flore i vegetacije. Navedene promjene kao i starost postojećih podataka ukazuje na potrebu sustavnog istraživanja flore Svilaje.

\section{Popis asocijacija i sveza navedenih u tekstu te njihov sintakosonomski položaj temeljen na podacima iz literature (korišteni su izvorni nazivi asocijacija bez njihove prethodne nomenklaturne validacije)}

CARPINO-FAGETEA SYLVATICAE Jakucs ex Passarge 1968

Fagetalia sylvaticae Pawłowski 1928

Aremonio-Fagion (Horvat 1950) Borhidi in Török et al. 1989

Ostryo-Fagenion Borhidi 1963

Seslerio autumnalis-Fagetum M. Wraber ex Borhidi 1963 


\section{QUERCETEA PUBESCENTIS Doing-Kraft ex Scamoni et Passarge 1959}

Quercetalia pubescenti-petraeae Klika 1933

Carpinion orientalis Horvat 1958

Querco-Carpinetum orientalis Horvatić 1939

Fraxino orni-Ostryion Tomažič 1940 (= Ostryo-Carpinion orientalis Horvat 1959)

Ostryo carpinifoliae-Quercetum pubescentis (Horvat) Trinajstić 1979

(incl. Seslerio autumnalis-Ostryetum carpinifoliae Horvat et Horvatić ex Horvat 1959)

CRATAEGO-PRUNETEA Tx. 1962 nom. conserv. propos.

Paliuretalia Trinajstić 1978

Paliuro-Petterion P. Fukarek 1962

ELYNO-SESLERIETEA Br.-Bl. 1948

Seslerietalia tenuifoliae Horvat 1930

Festucion pungentis Horvat 1930

Carici-Seslerietum robustae Tomić-Stanković 1970

Minuartio-Saxifragetum coriophyllae (Horvat 1942) Kušan 1969

FESTUCO-BROMETEA Br.-Bl. et Tx. ex Soó 1947

Scorzoneretalia villosae Kovačević 1959

Koelerienalia splendentis (Horvatić 1973) Terzi 2015

Chrysopogono grylli-Saturejion subspicatae Horvat et Horvatić ex Černjavski, Grebenščikov et Pavlović 1949 (= Chrysopogono grylli-Koelerion splendentis Horvatić 1973)

Koelerio splendentis-Festucetum illyricae Horvatić 1963 corr. Trinajstić 1992

Saturejion subspicatae Tomić-Stanković 1970

Centaureo rupestris-Caricetum humilis Horvat 1931

Saturejo subspicatae-Caricetum humilis Trinajstić 1999

Seslerio tenuifoliae-Caricetum humilis Horvat 1930

Bromo erecti-Seslerietum interruptae Trinajstić ex Terzi 2011

Saturejo subspicatae-Edraianthetum tenuifolii Horvat in Horvat et al. 1974

Minuartio capillaceae-Genistetum pulchellae Šegulja et Bedalov ex Terzi 2011

Scorzonerenalia villosae Terzi 2015

Scorzonerion villosae Horvatić ex Kovačević 1959

Scorzonerenion villosae Poldini et Feoli Chiapella 1993

Festuco-Armerietum canescentis Trinajstić et Šugar 1972

Ononido antiquorum-Brometum condensati Horvatić (1934) 1963

POLYGONO-POETEA ANNUAE Rivas-Mart. 1975

Polygono arenastri-Poetalia annuae Tx. in Géhu et al. 1972 corr. Rivas-Mart. et al. 1991

Polygono-Coronopodion Sissingh 1969

Lolio perennis-Plantaginetum majoris Beger 1930 (=Lolietum perennis Gams 1927)

EPILOBIETEA ANGUSTIFOLII Tx. et Preising ex von Rochow 1951

Galio-Alliarietalia Oberd. in Görs et T. Müller 1969

Geo urbani-Alliarion officinalis Lohmeyer et Oberd. in Görs et T. Müller 1969

Alliario petiolatae-Chaerophylletum temuli Lohmeyer 1955 


\section{Asocijacije kojima je sintaksonomski status nepoznat ili je prisutnost u Hrvatskoj dvojbe- na (Chytrý i dr. 2015, Mucina i dr. 2016).}

Narcisso-Gentianetum nivalis Lovrić et Rac 1988

Blysmo compressi-Juncetum thomasii Quézel 1964

\section{Zahvala}

Autori zahvaljuju Državnom hidrometerološkom zavodu na dostavljenim podacima o klimi za meteorološke postaje Knin, Drniš i Sinj za razdoblje od 1989.-2018.

\section{Literatura}

Adamović, L. (1911): Die Pflanzenwelt Dalmatiens. Werner Klinkhardt, Leipzig.

Adamović, L. (1929): Die Pflanzenwelt der Adrialänder. Gustav Fischer, Jena.

Barić, Lj. (1957): Eruptivi iz okolice Sinja u Dalmaciji, uz kraći osvrt na eruptivne pojave kod Knina, Vrlike i Drniša. Zbornik 2. kongresa geologa Jugoslavije, Sarajevo, 255-262.

Beck Mannagetta, G. (1901): Die Vegetationsverhältnisse der illyrischen Länder, begreifend Südkroatien, die Ouarnero-Inseln, Dalmatien, Bosnien und die Hercegovina, Montenegro, Nordalbanien, den Sandžak, Novipazar und Serbien. U: A. Engler \& O. Drude (ur.), Die Vegetation der Erde, Verlag von Wilhelm Engelmann, Leipzig, 2-15.

Biondić, R., Biondić, B., Rubinić, J., Meaški, H., Kapelj, S., Tepeš, P. (2009): Ocjena stanja i rizika cjelina podzemnih voda na krškom području u Republici Hrvatskoj. Geotehnički fakultet Sveučilišta u Zagrebu. 1-385.

Bogunović, M., Bensa, A. (2006): Tla krša - temeljni čimbenik biljne proizvodnje. U: Biondić, B., Božičević, J. (ur.), Hrvatski krš i gospodarski razvoj, Centar za krš, Zagreb, 41-50.

Bojanić, L. (1961): Allgemeiner geologischer Aufbau des Hauptkammes der Svilaja. Bulletin international de l'Académie Yougoslave des Sciences et des Beaux-arts, 6(4), 100.
Brkić, Ž., Biondić, R., Pavičić, A., Slišković, I. Marković, T., Terzić, J., Dukarić, F., Dolić, M. (2006): Određivanje cjelina podzemnih voda na Jadranskom slivu prema kriterijima Okvirne direktive o vodama EU. Arhiv Hrvatski geološki institut, Zagreb.

Brkić, Ž., Kuhta, M., Larva, O., Gottstein, S., Briški, M., Dolić, M. (2016): Ocjena stanja podzemnih voda na područjima koja su u direktnoj vezi s površinskim vodama $i$ kopnenim ekosustavima ovisnim o podzemnim vodama. Hrvatski geološki institut / Croatian Geological survey. Zavod za hidrogeografiju i inžinjersku geologiju. Zagreb. Chytrý, M., Daniëls, F. J. A., Di Pietro, R., Koroleva, N., Mucina, L. (2015): Nomenclature adjustments and new syntaxa of the Arctic, alpine and oro-mediterranean vegetation. Hacquetia, 14(2), 103-114.

Clementi, M. (2017): A Cross-disciplinary Study of the Work and Collections by Roberto de Visiani (1800-1878). Tesi di dottorato. Dipartimento di Scienze Storiche, Geografche e dell'Antichità. Università degli Studi di Padova, 1-375.

Čović, A. (2017): Florističke i meliorativne značajke šumskih kultura crnog bora (Pinus nigra J. F. Arnold) na području šumarija Drniš i Split. Šumarski fakultet Sveučilišta u Zagrebu, Završni specijalistički rad, 1-115.

Delić, A-A. (2010): Novi nalazi endemičnog leptira dalmatinskog okaša Proterebia afra dalmata (Godart, 1824) (Lepidoptera, Satyrinae) u Dalmaciji (Hrvatska). U: Matas, M. i Faričić, J. (ur.): Zagora između stočarsko-ratarske tradicije te procesa litoralizacije i globalizacije: knjiga sažetaka / Znanstveni skup s međunarodnim sudjelovanjem, Zadar - Dugopolje, 19-21. listopada 2010, 13. Durbešić, A., Fuerst-Bjeliš, B. (2016): Tipovi i trendovi promjene pejzaža planine Svilaje - Ogorje / Types and trends in landscape changes at Svilaja - Ogorje mountain area. Ekonomska i Ekohistorija, 12(12), 208-221. 
Durbešić, A., Milković, I. (2005): Pošumljavanje neobraslog šumskog zemljišta na južnim padinama Svilaje-Muć s ciljem protuerozijskog djelovanja. Zbornik radova međunarodnog znanstvenog skupa Protuerozijska i vodozaštitna uloga šume i postupci njezina očuvanja i unapređenja, Šumarski list 13, 133 - 143.

Forenbacher, A. (1913): Visijanijevi prethodnici u Dalmaciji. Rad JAZU 200, 205-208.

Forenbacher, A. (1914): Istorijski pregled botaničkih istraživanja kraljevine Dalmacije od Visijanija do danas. Rad JAZU, 202, 51-95.

Golubić, V. (1999): Izložba slika. Orhideje (Orchidaceae) od Kaštela do planine Svilaje. Katalog izložbe. Split.

Govaerts, R. (2019): World Checklist of Liliaceae. Facilitated by the Royal Botanic Gardens, Kew. Published on the Internet; http://wcsp.science. kew.org (Retrieved 2 August 2019).

Hirc, D. (1903-1912): Revizija Hrvatske flore. Rad JAZU, 155-190.

Hirc, D. (1906): Revizija hrvatske flore. Rad JAZU, 167, 8-128.

Hirc, D. (1908): Revizija hrvatske flore. Rad JAZU, 173, 38-136.

HIRC, D. (1909): Iz bilinskog svijeta Dalmacije. Glasnik hrvatskog prirrodoslovnog društva (Zagreb), 21, 6-28.

Hirc, D. (1910): Revizija hrvatske flore. Rad JAZU, 181, 1-52.

Hirc, D. (1912): Revizija hrvatske flore. Rad JAZU, 190, 170-275.

Horvat, I. (1930): Vegetacijske studije o hrvatskim planinama. I. Zadruge na planinskim goletima. Rad JAZU, 238, 1-96.

Horvat, I. (1931): Vegetacijske studije o hrvatskim planinama 2. Zadruge na planinskim stijenama i točilima. Rad JAZU, 241, 147-206.

Horvat, I. (1932): Istraživanje vegetacije na Dinarskim planinama. Ljetopis JAZU za godinu 1930/31, 44, 122-130.

Horvat, I. (1938): Biljnosociološka istraživanja šuma u Hrvatskoj. Glasnik za šumarske pokuse, 6, 127-279.
Horvat, I. (1962): Vegetacija planina zapadne Hrvatske (s 4 karte biljnih zajednica sekcije Sušak). Prirodoslovna istraživanja JAZU, Acta biologica II, 30, 1-179.

Horvat, I., Glavač, V, Ellenberg, H. (1974): Vegetation Südosteruropas. Gustav Fischer Verlag, Stuttgart.

Ivanović, A., Sikirica, V., Marković, S., Sakač, K (1977): Osnovna geološka karta SFRJ 1:100000, list Drniš (K 33-9). Geološki zavod, Zagreb, Savezni geološki zavod, Beograd.

Ivanović, A., Sikirica, V., Sakač, K (1978): Tumač Osnovne geološke karte SFRJ 1:100000, list Drniš (K 33-9). Geološki zavod, Zagreb, Savezni geološki zavod, Beograd.

Janchen, E. (1908): Eine botanische Reise in die Dinarischen Alpen und den Velebit. Mitteilungen des Naturwissenschaftlichen Vereins an der Universitaet Wien, 6, 69-97.

Janchen, E. (1910): Die Edraianthus-Arten der Balkanländer. (Tafel 1-4.). Mitteilungen des Naturwissenschaftlichen Vereins an der Universitaet Wien, 8, 1-40.

Janchen, E., Watzl, B. (1908): Ein Beitrag zur Kenntnis der Flora der Dinarischen Alpen. Unter Mitwirkung von A. v. Degen (Budapest). Österreichische botanische Zeitschrift, 058: 100-111, 161-168, 204-209, 244-250, 288-304, 351-363, 392-396.

Jasprica, N., Škvorc, Ž., Pandža, M., Milović , M., Kovačić, S., Sandev, D., Lasić, A., Purger, D., Caković, D., Stešević, D., Krstonošić, D. (2020): Phytogeographic and syntaxonomic diversity of wall vegetation (Cymbalario-Parietarietea diffusae Oberdorfer 1969) in the SE Europe. Plant Biosystems, in review.

Jedlovski, D. (1952): Prilog istraživanju areala bukve u Dalmaciji. Šumarski list 76(5-6): 160-164.

Jelaska, V., Kolar-Jurkovšek, T., Jurovšek, B., Gušić, I. (2003): Triassic beds in the basement of the Adriatic-Dinaric carbonate platform of Mt. Svilaja (Croatia). Geologija, 46/2, 225-230.

Kerner, F. (1907): Vorläufige Mitteilung über Funde von Triaspflanzen in der Svilaja planina. 
Verhandlungen der Kaiserlich-Königlichen Geologischen Reichsanstalt Wien, 294-333.

Kerner, F. (1915): Tektonik der Südwest-Abhanges der Svilaja planina. Verhandlungen der Kaiserlich-Königlichen Geologischen Reichsanstalt Wien, 285-302.

Kirigin, B., Šinik, N., Bertović, S. (1971): Klimatski podaci SR Hrvatske. Građa za klimu Hrvatske, ser. II., 5, Hidrometeorološki zavod Hrvatske, 1-118. Kranjčev, R. (2002): Od Muća do vrha Svilaje. Priroda, 92(4), 28-33, Zagreb.

Kranjčev, R. (2005): Hrvatske orhideje: prilozi za hrvatsku floru: staništa, svojte, hibridi, zaštita. AKD Zagreb, 1-518.

Kranjčev, R. (2006): Bosanski ljiljan (Lilium bosniacum (Beck) Beck ex Fritsch). Šumarski list, 130(5-6): 175-181.

Kranjčev, R., Šešok, D. (2016): A revision of the genus Fritillaria (Liliaceae) in Croatia. Natura Croatica, 25(2): 185-212.

Kušan, F. (1969): Biljni pokrov Biokova (Flora i vegetacija). JAZU, Odjel za prirodne nauke, Prirodoslovna istraživanja / knjiga 37, Acta Biologica V. Zagreb, 5-187.

Lovrić A. Ž., Rac, M. (1989): Reliktna visokoplaninska vegetacija najhladnijih vrhova na južnim primorskim Dinaridima i njezino paleogeografsko porijeklo. Acta Biokovica 5, 131-148.

Lovrić, A. Ž., Rac, M. (1987): Fitocenološka analiza vegetacije Biokovskog područja. Morske i kopnene fitocenoze. Acta Biokovica 4, 97-142.

Lovrić, A. Ž., Rac, M. (2005): Geobotanical zoning in Zagora ranges of Dalmatia (Southwest Dinarides). 17th International Botanical Congress, PO730 / 356, Wien.

Lovrić, A. Ž., Rac, M., Bedalov, M., Šegulja, N. (1987): Prilog fitogeografiji Svilaje i njezina povezanost s Biokovom. Acta Biokovica 4, 189-203.

Lovrić, A. Ž., Rac, M., Sekulić, B. (1989): Phytogeography and synecology of the Svilaja mountain range in Dalmatia. Periodicum Biologorum, 91(1), 177-178.
Marković, Lj. (1964): Fitocenološka istraživanja ruderalne vegetacije u Hrvatskoj. Doktorska disertacija, Botanički zavod PMF-a Sveučilišta u Zagrebu, Zagreb.

Marković, Lj. (1992): Die Vegetation des Verbandes Alliarion in Kroatien. Acta Botanica Croatica, 51, 77-88.

Marković-Gospodarić, Lj. (1965): Prilog poznavanju ruderalne vegetacije kontinentalnih krajeva Hrvatske. Acta Botanica Croatica, 24, 91-136.

Mazzoleni, A. (1845): Gita botanica in Dalmazia. Giornale Euganeo di Scienze, Letere, Arti e Varietà, 4, 127-132.

Meštrović, Š. (1972): Uspijevanje primorskog bora Pinus pinaster Ait. u kulturama Hrvatske. Šumarski list, 96(5-6), 179-216.

Milović, M., Karađole, J. (2016): Novi nalazi stenoendemične vrste Arenaria orbicularis Vis. u Hrvatskoj. Glasnik hrvatskog botaničkog društva, 4(2), 25-29.

Milović, M., Pandža, M., Jasprica, N., Tafra, D. (2013): Floristička istraživanja na planini Svilaji (1508 m), Dalmacija. U: Alegro, A. i I. Boršić (ur.), Zbornik sažetaka Četvrtog Hrvatskog Botaničkog Simpozija s međunarodnim sudjelovanjem. Hrvatsko botaničko društvo, Split, 118-119.

Mucina, L., Bültmann, H., Dierßen, K., Teurillat, J. P., Raus, T., Čarni, A., Šumberová, K., Raus, T., Di Pietro, R., Gavílan García, R., Chytrý, M., Iakushenko, D., Schaminée, J. H. J., Bergmeier, E., Santos Guerra, A., Daniëls, F. J. A., Ermakov, N.,Valachovic, M., Pignatti, S., Rodwell, J. S., Pallas, J., Capelo, J., Weber, H. E., Lysenko, T., Solomesh, A., Dimopolous, P., Aguiar, C., Freitag, H., Hennekens, S. M., Tichý, L. (2016): Vegetation of Europe: hierarchical floristic classifcation system of vascular plant, bryophyte, lichen, and algal communities. Applied Vegetation Science, 19 (Suppl. 1), 3-264.

Muratović, E., Robin, O., Bogunić, F., Šoljan, D., Šiljak-Yakovlev, S. (2010): Does Lilium bosniacum merit species rank? A classical and molecular-cytogenetic analysis. Plant Systematics and Evolution, 252, 97-109. 
Nikolić, T., Milović, M., Bogdanović, S., Jasprica, N. (2015): Endemi u hrvatskoj flori, Alfa d.d., Zagreb. Nikolić, T., ur. (2019): Flora Hrvatske baza podataka/ Flora Croatica Database (URL: http://hirc. botanic.hr/fcd/). Prirodoslovno-matematički fakultet, Sveučilište u Zagrebu (datum pristupa: 10. 8. 2019).

Ozenda, P. (1975): Sur les étages de végétation dans les montagnes du bassin méditerranéen. Documents de Cartographie Ecologique, 16, 1-32.

Papeš, J., Marinković, R., Raić, V., Magaš, N., Sikirica, V. (1982): Osnovna geološka karta SFRJ 1:100000, list Sinj K 33-10. Geološki zavod, Zagreb, Savezni geološki zavod, Beograd.

Petter, F. (1832): Botanischer Wegweiser in der Gegend von Spalato in Dalmatien. Battara Verlag, Zara.

Raić, V., Papeš, J., Sikirica, V., Magaš, N. (1984): Tumač Osnovne geološke karte SFRJ, 1:100000, list Sinj (K 33-10). Geoinženjering, Institut za geologiju Sarajevo, Geološki zavod, OOUR za geologiju i paleontologiju. Savezni geološki zavod, Beograd, 1-52.

Regula-Bevilacqua, Lj. (1985-1986): Vrtoglav ili škuri ljiljan. Priroda, 74(6), 177.

Rivas-Martínez, S. (1982): Etages bioclimatiques, secteur chorogiques et sésies de végétation de l'Europe méditerranéenne. Ecologia Mediterranea, 8(1-2), 275-288.

Rivas-Martínez, S., Penas, A., Diaz, TE. (2004): Mapa Biogeográfico de Europa (URL: http://webs.ucm. es/info/cif/form/maps.html). University of Léon, Spain: Cartographic Service. (datum pristupa: 1. 2. 2020).

Schlosser, K. J., Vukotinović, Lj. (1869): Flora Croatica, Zagreb.

Šegota, T., Filipčić, A. (2003): Köppenova podjela klima i hrvatsko nazivlje, Geoadria, 8(1), 17-37.

Šegota, V (2016): Proljetna flora južnih padina Svilaje. 5. Hrvatski botanički simpozij s međunarodnim sudjelovanjem, Primošten, 22.-25. rujna 2016. Knjiga sažetaka, Rešetnik, I. i Z. Ljubešić (ur.), str. 20.
Šegota, V., Jasprica, N., Bogdanović, S., Pandža, M., Milović, M., Alegro, A.L. (2016): Distribution of the species Matthiola fruticulosa (L.) Maire (Brassicaceae) in Croatia. Glasnik hrvatskog botaničkog društva, 4(2), 20-25.

Škvorc, Ž., Jasprica, N., Alegro, A., Kovačić, S., Franjić, J.,Krstonošić, D., Vraneša, A., Čarni, A. (2017): Vegetation of Croatia: Phytosociological classifcation of the high-rank syntaxa. Acta Botanica Croatica, 76(2), 200-224.

Sremac, J., Fio Firi, K., Vudrag, M. (2017): Geološke karakteristike šireg područja Ogorja: 250 milijuna godina povijesti zapisane $u$ stijenama. U: Kapetanović, V. (ur): Zbornik „Župa Ogorje putovima života i vjere između Svilaje i Moseća“. Kulturni sabor Zagore, Split, 25-39.

Šušnjara, B., Šušnjara, A. (1983): The geologic column oft he Lower Triass at Muć (Southern Croatia). Acta geologica, 13(1), 1-25, Zagreb.

Terzi, M. (2015): Numerical analysis of the order Scorzoneretalia villosae. Phytocoenologia 45(1-2), 11-32.

Trinajstić, I. (1987): Sintaksonomski pregled biljnih zajednica planine Biokovo. Acta Biokovica, 4: 143-174.

Trinajstić, I. (1992): Sintaksonomska analiza pašnjačke zajednice Festuco-Koelerietum splendentis H-ić 1963. Acta Botanica Croatica, 51, 103-112.

Trinajstić, I. (1998): Fitogeografsko raščlanjenje klimazonalne šumske vegetacije Hrvatske, Šumarski list, 9-10, 407-421.

Visiani, R. (1826): Stirpium dalmaticarum specimen, Typis Crescinianis, Patavii (Radić, J., 1978, Ogled dalmatinskog bilja, Prijevod s latinskog, Čakavski sabor, Split).

Visiani, R. (1842-1852): Flora Dalmatica, I-III, Lipsiae.

Visiani, R. (1972): Florae Dalmaticae supplementum. Memor. Del R. Istituto, XVI(I), Venetiis.

Vladović, D., Mekinić, S., Piasevoli, G., Hruševar, D., Ževrnja, N., Šimić, L., Damjanović, T. (2019): Značajni krajobraz Sutina. Javna ustanova za upravljanje zaštićenim dijelovima prirode na području Splitskodalmatinske županije - „More i krš“" i Prirodoslovni muzej i zoološki vrt u Splitu. Split, 1-56. 
Vladović, D., Rađa, T., Ževrnja, N., (2012): Vaskularna flora i vegetacija jama na području srednje Dalmacije, Hrvatska. U: Čovjek i krš 2011. Zbornik radova Znanstveno-stručnog skupa Čovjek i krš 13. - 16. 10. 2011. Bijakovići - Međugorje (Lučić, I. i J. Mulaomerović, ur.). 241-250.

Vlahović, I., Tišljar, J., Velić, I., Matičec, D. (2005): Evolution of the Adriatic Carbonate Platform: Paleogeography, main events and depositional dynamics. Paleogeography, paleogeography, paleoecology, 3 - 4, 333-360

Vrbek, M., Buzjak, S., ur. (2019): Virtualni herbarij CNHM. Hrvatski prirodoslovni muzej. http:// www.hpm.hr/Odjeli i zbirke/Botanički odjel/ CNHM.
Vukadinović, V. (2019): Interaktivna pedološka karta RH s legendom (prema Bogunović, M., Vidaček, Ž., Racz, Z., Husnjak, S., Sraka, M. (1996): Namjenska pedološka karta Republike Hrvatske mjerila 1:300.000 s tumačem karata. Sveučilište u Zagrebu, Agronomski fakultet, Zavod za pedologiju). http://tlo-i-biljka.eu/GIS.html

Vukelić, J., Mikac, S., Baričević, D., Bakšić, D., Rosavec, R. (2008): Šumska staništa i šumske zajednice u Hrvatskoj. Nacionalna ekološka mreža. Državni zavod za zaštitu prirode, Zagreb, 6-263.

Ževrnja, N., Vladović, D. (2005): The genus Crocus L. in the flora of Svilaja mountain. Natura Croatica, 14(4), 363-368. 